\title{
Dünü ve Bugünüyle Dünyada ve Türkiye'de Maden İşçilerine Yönelik İs Sağlığı ve Güvenliği Bağlamında Yaşanan Gelişmeler Üzerine Bir Değerlendirme
}

\author{
An Evaluation on Yesterday and Today with the world and in Turkey \\ Towards the Mine Workers' Occupational Health and Safety \\ Developments in Context
}

\section{Atanur Karaahmetoğlu' 1 (1)}

Öz

Bu araştırmanın amacı, iş sağlığı ve güvenliği alanında maden işçilerine yönelik ne gibi gelişmelerin yaşandığı ve bu yaşanan gelişmelerin maden iş̧̧ilerini ne şekilde etkilediğini analiz etmektir. Bu doğrultuda devletlerin iş sağlığı ve güvenliği açısından maden işçilerine yönelik izledikleri politikalar ve bu alanda attıkları adımlar ele alınmıştır. Zira, tarihin her döneminde maden işçileri beden gücüne dayanarak çalışmış ve birçok tehlikeye maruz kalmıştı. Ancak, bu duruma her devletin gösterdiği reaksiyon farklı olmuştur. Kimi devletler maden işçilerine karşı zor kullanma yoluna giderken, kimi devletler de maden işçilerini koruyucu politikalar izlemiştir. Bu koruyucu politikalar neticesinde de maden işçilerine yönelik iş sağlığı ve güvenliği alanında kanuni düzenlemeler yapılmıştır. Ancak, yapılan bu kanuni düzenlemeler her zaman için bir çözüm getirmemiştir. Kanuni düzenlemeler yapılmasına karşın, çoğu zaman kanun hükümlerinin uygulanmaması ya da eksik uygulanması nedeniyle madenlerde görülen olumsuz tablo değişmemiştir. Ulusal mevzuatımızda da maden işçilerine yönelik koruyucu nitelikte birçok hukuki düzenleme yapılmış olmasına karşın, çoğu zaman bu kanuni düzenlemeler hayata geçirilememiştir.

\section{Anahtar Kelimeler}

Maden iş̧̧isi, İ̧s sağlığı ve güvenliği, Koruyucu politikalar, Hukuki düzenleme, İş sağlığı ve güvenliği sistemi

1 Sorumlu Yazar: Atanur Karaahmetoğlu (Arş. Gör.), Kırklareli Üniversitesi, İktisadi ve İdari Bilimler Fakültesi, Çalışma Ekonomisi ve Endüstri İlişkileri Bölümü, Kırklareli, Türkiye. Eposta: atanurkartal@hotmail.com ORCID: 0000-0001-8306-3178

Attf: Karaahmetoglu, A. (2020). Dünü ve bugünüyle dünyada ve Türkiye'de maden işçilerine yönelik iş sağlığı ve güvenliği bağlamında yaşanan gelişmeler üzerine bir değerlendirme. Sosyal Siyaset Konferansları Dergisi, 79, 129-165. https://doi. org/10.26650/jspc.2020.79.0125 


\begin{abstract}
The purpose of this study was to analyze what developments have occurred towards miners in the field of occupational health and safety and how these developments have affected miners. In this direction, the policies of the states towards mine workers in terms of occupational health and safety and the steps they have taken in this area are discussed. Because, in every period of history, mine workers worked on the basis of their body power and they were exposed to many dangers. However, the reaction of each state to this situation was different. Some states have used mine workers hard, while some states have followed mine workers' protective policies. As a result of these protective policies, legal arrangements have been made in the field of occupational health and safety for mine workers. However, these legal regulations have not always brought a solution. Despite legislative arrangements, the negative picture observed in the mines has not changed, mostly due to the lack of enforcement or incomplete enforcement of the provisions of the law. Although there are many protective legal arrangements for mine workers in our national legislation, these legal regulations have not been put into practice most of the time.
\end{abstract}

\title{
Keywords
}

Miner, Occupational health and safety, Protective policies, Legal regulation, Occupational health and safety system 


\section{Extended Summary}

The origin of mining activities is quite old. Even in ancient times, many civilizations engaged in mining activities. For this reason, many civilizations have benefited from the blessings of the mines.

In this direction, many states have been enriched by mines. For this, increasing the production in the mines has become inevitable. However, this situation also caused some negative results. For example, mining workers started to work under more difficult conditions. In addition, risks threatening occupational health and safety have increased in mines. In other words, mines have turned into areas of great risk.

For these reasons, how healthy and safe mines are has become controversial over time. Many scientists have come up with different ideas in terms of occupational health and safety. For example, from the 16th century onwards, scientists discussed how healthy and safe mines were. They investigated the factors that impaired the health of mining workers. They proposed solutions in this direction. They found that there was a relationship between the faults of the mine workers and the work done. However, the most important developments regarding mining workers in Europe have been experienced along with industrialization. With industrialization, the working conditions of the miners deteriorated. In addition, many occupational accidents occurred in the mines and occupational diseases also increased significantly. With these developments, many legal regulations were made in the field of occupational health and safety for mining workers. However, the negative factors experienced in the mines were not completely prevented.

Similarly, there were many important developments for mining workers in the USA with industrialization. For example, the relationship between disease and the work done was investigated. In addition, it examined whether the occupational health and safety methods applied in the mines were sufficient. After these developments, legal regulations were made in the USA in the field of occupational health and safety for mine workers. However, in the USA, the disadvantages experienced in the mines were not completely prevented.

The first important developments for mining workers in our country started with the industrialization process. However, although the industrialization process in our country started later as compared to Europe, many legal 
arrangements were made for mining workers. The poor working conditions in the mines were also very effective in making these legal regulations since the working conditions of mining workers had deteriorated considerably from the second half of the 19th century. Also, there were no favorable conditions for occupational health and safety in the mines. For these reasons, many consecutive legislative arrangements were made for mine workers. However, the desired results have not been achieved.

In the 20th century, many legal arrangements were made for mining workers in our country. The basis for these legal regulations was the idea of creating occupational health and safety in mines. For this reason, there were provisions made for mining workers in the legal regulations of labor law. However, the basic law concerning mine workers in our country was the Occupational Health and Safety Law No. 6331, which came into force in 2012. Occupational health and safety came into force as a law and directly addressed occupational health and safety. Although many laws concerning mine workers have come into force in our country, there have been many problems in the mines especially since the 2010s.Many mining accidents occurred during this period and many workers died. Therefore, if the legal regulations in the field of occupational health and safety are not applied, it does not make sense.

As a result, there have been many developments in the field of occupational health and safety for mine workers, both in the world and in our country. However, accidents continue to occur in mines. For this reason, both employers and workers must act in accordance with legal regulations and act in accordance with occupational health and safety. Consequently, in this study, an evaluation was made to determine whether the necessary steps were taken to ensure occupational health and safety in the mines by researching the developments in the world and in our country towards mining workers. For this reason, important developments in the field of occupational health and safety for mining workers, both in the world and in our country, were examined. 


\section{Dünü ve Bugünüyle Dünyada ve Türkiye’de Maden İşçilerine Yönelik İş Sağlığı ve Güvenliği Bağlamında Yaşanan Gelişmeler Üzerine Bir Değerlendirme}

İş sağlığı ve güvenliği, iş sağlı̆̆1 ve güvenliğine yönelik gerekli önlemlerin alınması anlamına gelmekle birlikte, alınan bu önlemlerin uygulanması anlamına da gerekmektedir (Özveri, 2015, ss. 77-78). Zira, iş sağlı̆̆ ve güvenliği bir taraftan çalışan sağlığını koruyan, diğer taraftan da iş sağlığı ve güvenliğine dönük bir dizi önlem alan çok yönlü uygulamalar bütünüdür (Sümer, 2017, ss. 5-7;Öztürk, 2015, ss. 16-19). Bu nedenle, iş sağlığ1 ve güvenliği kavramı "iş sağlı̆ğı" ve "iş güvenliği” kavramlarının bir araya gelmesi ile oluşan çok boyutlu ve değişken bir kavramdır (ÇSGB, 2017, ss. 17-18;:Selek, 2018, ss. 25-28). Buna göre, iş sağlığ1; sağlıklı bir iş ortamının tesis edilebilmesi için birtakım sağlık kurallarının oluşturulması ve bu kurallara riayet edilmesi anlamına gelmektedir (Tozkoparan ve Taşoğlu, 2011, ss. 183). Aksi halde, 21 Haziran 1981 tarihli İş Sağlığı ve Güvenliği ve Çalışma Ortamına İlişkin 155 sayılı ILO Sözleşmesinin 3. maddesinde de düzenlendiği üzere, iş ile bağlantılı hastalık ve sakatlıkların yanı sıra, fiziksel ve zihinsel açıdan insan sağlığını etkileyen unsurlar da sağlıksız bir çalışma ortamının oluşmasına neden olmaktadır (ILO, 2020, 2 Şubat). Zira, 7 Haziran 1985 tarihli Sağlık Hizmetlerine İlişkin 161 sayı1ı ILO Sözleşmesinin 1. maddesine göre, zihinsel ve fiziksel açıdan sağlık koşullarına, işin niteliğine uygun ve önleyici nitelikte sağlık hizmetlerinin verilmesi gerektiği ve sağlıklı ve güvenli bir çalışma ortamının oluşturulması ve bu sistemin de sürdürülebilir olması gerektiği düzenlenmiştir (ILO, 2020, 7 Şubat). Buna göre iş sağlığ 1 ve güvenliği kurallarına uyulması halinde sağlıklı ve huzurlu bir çalışma ortamı da tesis edilmiş olacaktır (Akpınar ve Çakmakkaya, 2014, s. 275).

$\mathrm{Bu}$ doğrultuda iş sağlığ bir iyilik hali içinde olmasıdır (Ak1, 2014, s. 3). Zira, bu durumda işçi çevreye de uyum sağlamış olmaktadır (Yılmaz, 2009, s. 7). Ancak şu husus belirtilmelidir ki, iş sağlığı sadece işçilerin sağ lığını ilgilendiren bir kavram değildir. İş sağ lı̆̆1, işçilerin yanında işten etkilenebilecek üçüncü kişilerin de sağlığını korumayı amaç edinmiştir (Şen, 2015, s. 120). İş güvenliği ise, işçilerle birlikte işyerinin güvenliğinin sağlanması için oluşturulan kurallar bütünüdür (Tozkoparan ve Taşoğlu, 2011, s. 183). Bu nedenle iş güvenliği, işyerinde kullanılan araç, gereç ve makinelerin güvenli bir şekilde kullanılmasını ve çalışanların muhtemel 
risklere karşı korunmasını amaçlayan bir sistemdir (Jonathan ve Mbogo, 2016, ss. 2-3). Ayrıca iş güvenliği, bir yandan işin güvenli bir şekilde yapılmasını hedeflerken, diğer yandan güvenli ortamın sürdürülebilir olmasını da amaçlamaktadır (Şen, 2015, s. 120). Bu bağlamda iş sağlı̆̆ ve güvenliğii, çalışanların sağlık içinde ve güvenli bir ortamda çalışabilmesi için tıbbi ve teknik açıdan önlemler alınmasını teşvik eden bir sistemdir (Sümer, 2017, ss. 5-7;Öztürk, 2015, ss. 16-19). Bunun yanında iş sağlığı 1 ve güvenliği, teknolojik gelişmelere bağlı olarak kullanılan araç, gereç ve malzemelerin zararlı etkilerini de azaltmayı amaçlayan bir sistemdir (Jonathan ve Mbogo, 2016, s. 2). Bu nedenle, iş ortamında bulunan kimyasallar, zehirli gazlar, sıcaklık, basınç, işçinin çalışırken kullandığı aletler, materyaller, bunların kullanılması sırasında ortaya çıkan gaz, toz, gürültü, işçilerin kullandıkları makinelerden kaynaklı riskler iş sağlı̆̆ ve güvenliğinin ilgi alanına girmektedir (Yamakoğlu, 2016, ss. 25-27). Bu nedenle, iş sağlığ 1 ve güvenliği, işyeri içinde iş sağlığ ve güvenliğine yönelik tedbirlerin alınmasını zorunlu kılmakla birlikte, işyeri dışında da iş sağlığı ve güvenliğine yönelik tedbirlerin alınmasını zorunlu kılmaktadır (Kol, 2016, s. 4). Buna göre, gerek işyeri içinde gerek işyeri dışında iş sağlı̆̆ 1 ve güvenliği açısından elverişli çalışma koşullarının oluşturulması büyük önem taşımaktadır (Yılmaz, 2009, s. 8).

$\mathrm{Bu}$ açıklamalardan hareketle iş sağlı̆ğ ve güvenliği kavramı, dar anlamda iş sağlığg ve güvenliği veyahut geniş anlamda iş sağlığ1 ve güvenliği şeklinde tanımlanabilecektir. Dar anlamda iş sağlığı ve güvenliği, çalışanın bedenen ve ruhen sağlığının zarar görmemesi adına muhtemel iş ve işyeri kaynaklı risklerin önlenmesi olarak ifade edilebilir (Şen, 2015, s. 124). Bu şekilde ileride görülmesi muhtemel vahim sonuçların engellenmesi mümkün hale gelmektedir. Zira, iş kazası ve meslek hastalıklarının önlenmesi açısından iş sağlığı ve güvenliğine uygun hareket edilmesi büyük önem taşımaktadır (Sümer, 2017, ss. 6-7). Bu bağlamda iş sağlığ 1 ve güvenliğinin sağlanabilmesi açısından belli yükümlülüklerin yerine getirilmesi gerekmektedir. Bunun içindir ki, işverenlerin çalışanların risklere karşı korunması için gerekli tüm önlemleri alması gerekmektedir. Ancak, zaman içinde iş sağlı̆̆ 1 ve güvenliği kavramının kapsamı genişlemiş ve işyeri içinden kaynaklanan risklerin yanında, işyeri dışından kaynaklanan risklere karşı da önlem alınması ve işçilerin korunması şeklinde iş sağlığ1 ve güvenliği kavramı ele alınmıştır. Ayrıca, sadece işçiler değil, işyerinin faaliyetlerinden etkilenebilecek sosyal çevrenin de korunması gerektiği anlayışı benimsenmiştir (Çiçek ve Öçal, 2016, s. 109). Bu nedenle, iş sağlı̆̆ 
ve güvenliğini sağlamak açısından sadece işveren sorumlu tutulmamış, devlete de sorumluluk yüklenmiştir (Balkır, 2012, s. 59). Buna göre, devletin iş sağlığ1 ve güvenliğine dönük koruyucu adımlar atması ve kanuni düzenlemeler yapması gerekmektedir (Süzek, 2017, s. 891).

Bu doğrultuda iş sağlığı ve güvenliği, muhtemel risk ve tehlikelerin azaltılmasını amaçlayan kurallar bütünüdür. Bunun içindir ki, iş sağlığı ve güvenliği, yapılan işten etkilenebilecek üçüncü kişilerin, müşterilerin ve sosyal çevrenin de daha sağlıklı ve güvenli bir ortamda yaşamasını hedefleyen bir anlayıştır (Şen, 2015, s. 83). Bu nedenle, iş sağlığı ve güvenliği sistemi üretimin bütün safhalarının sağlıklı ve güvenli bir şekilde gerçekleştirilmesi amacına hizmet etmektedir (Akpınar, 2018, s. 5). Bunun için, bireylerin sağlı̆̆ı ve güvenliği esas alınmaktadır (Akpınar, 2018, s. 261). Bu nedenle, iş sağlığı ve güvenliği kavramının temelinde, bireylerin sağlıklı bir yaşam sürdürebilmesi için uygun şartların oluşturulması düşüncesi yatmaktadır (Filizöz ve Kocabacak, 2016, ss. 21-22; Sümer, 2017, ss. 3-5). Zira, iş sağlığ 1 ve güvenliğindeki eksiklikler yaralanmalara hatta ölümlere yol açarak vahim sonuçların ortaya çıkmasına neden olmaktadır (Eddington, 2006, s. 2). Dolayısıyla, gerekli önlemlerin alınmaması halinde çalışanların sağlıklı bir yaşam sürmesi mümkün bulunmamaktadır (Kılkış, 2012, s. 25). Bir başka ifadeyle, çalışanların risklere karşı korunması çalışan sağ lığı için bir gerekliliktir (Jonathan and Mbogo, 2016, s. 1).

İş sağlığ1 ve güvenliğinin sağlanması açısından, çeşitli tehlikelere karşı çalışanların korunması için gerekli tedbirlerin alınması esastır (Özveri 2015, ss. 77-78). Bu nedenle, işverenlerin iş sağlığ ve güvenliği açısından koruyucu nitelikte tedbirleri alması gerekmektedir. Buna göre, bir işverenin işyerinde çalışan işçi, o işverenin işçisi olsun ya da olmasın işverenin iş sağlı̆̆ı ve güvenliğini sağlama yükümlülüğü bulunmaktadır (Balkır, 2012, s. 59). Zira, iş sağlığ̀ ve güvenliği, çalışan sağlı̆̆ı, işyeri güvenliği, iş verimliliği açısından son derece önemlidir. $\mathrm{Bu}$ nedenle, madenler ile ilgili yapılan kanuni düzenlemelerde iş sağlığı ve güvenliğine yönelik de düzenlemeler getirilmiştir. Zira, maden işçilerinin selameti ve üretimin verimliği açısından iş sağlığı ve güvenliği büyük öneme sahiptir (Turhan, 2016, s. 31). Örneğin, ABD'de 1977 yılında yürürlüğe giren Federal Maden Güvenliği ve Sağlığı Kanunu'nda daha sonraki yıllarda iş sağlığı ve güvenliği açısından birçok önemli düzenleme getirilmiş ve madenlerde iş sağlığ 1 ve güvenliği standartlarının yükseltilmesi amaçlanmıştır (Sökmen, 2016, ss. 3-4). 


\section{Dünyada Maden İşçilerini İlgilendiren İş Sağlığı ve Güvenliği Alanında Yaşanan Gelişmeler}

Tarihin ilk dönemlerinden itibaren madencilik faaliyetlerinin yapıldığ 1 bilinmektedir (Öztoprak, 2015, s. 27). Zira, antik çağlarda dahi birçok medeniyet madencilik faaliyetleri ile uğraşmış ve madenciliğin nimetlerinden faydalanmıştır. Bu nedenle madencilik faaliyetleri, tarihi süreç içinde dünya genelinde giderek yaygınlaşmış ve maden üretiminde de farklı politikalar izlenmiştir (Topaloğlu, 2011, s. 1). Ayrıca, izlenen bu politikaların bir sonucu olarak bazı devletler madenlerde üretimi arttırabilmek adına maden işçilerine zor kullanma yoluna giderken, bazı devletler de üretimi arttırabilmek adına maden işçilerinin çalışma şartlarını iyileştirme ve iş sağlığı ve güvenliğini geliştirme politikaları izleme yoluna gitmiştir (Özveri, 2015, s. 26). Şu bir gerçektir ki, madencilik alanında yaşanan gelişmeler ve izlenen politikalar da iş sağlı̆̆ ve güvenliği açısından maden işçilerini oldukça etkilemiştir (TMMOB, 2011, s. 3).

İş sağlığı ve güvenliği alanında yaşanan gelişmelerin temel dinamikleri ilk olarak antik çağlarda ortaya çıkmıştır (Topaloğlu, 2011, ss. 1-2). Lakin, sistemli ve belli kurallara dayanan bir iş sağlığı ve güvenliği anlayışı ancak 19. yüzyılda ortaya çıkmıştır.

İş sağlığı ve güvenliği ilk olarak Antik Mısır, Babil Krallığı ve Antik Yunan gibi medeniyetlerde tartışılmış ve bu alanda çeşitli adımlar atılmıştır (Baycık, 2006, s. 37). Örneğin, Antik Mısır'da iş sağlığı ve güvenliği alanında ilk önemli gelişmeler yaşanmış ve işçilerin daha sağlıklı ve güvenli bir ortamda çalıştırılmasının önemi anlaşılmıştır. Özellikle, bu dönemde yaşayan bir hekim olan İmhotep iş sağlığ 1 ve güvenliği açısından önemli tespitlerde bulunmuş işçilerde görülen bel rahatsızlıklarının yapılan işle ilgili olabileceği savını ileri sürmüştür. Babil Krallığı döneminde de iş sağlığı ve güvenliği açısından önemli gelişmeler yaşanmış ve bu dönemde Hammurabi Kanunları olarak bilinen kanunlarda iş sağlığ 1 ve güvenliği konusu da ele alınmıştır. Yaşanan bu gelişmeler şüphesiz maden işçilerine yönelik ileride yapılacak araştırmalara ve düzenlemelere de 1şık tutmuştur (Şen, 2015, s. 121).

Antik Yunan döneminde de iş sağlığı ve güvenliği alanında önemi gelişmeler yaşanmış ve işçilerin sağlığını etkileyebilecek faktörler açısından birtakım araştırmalar yapılmıştır. Zira, bir tarihçi ve filozof olan Heredot, tarafindan 
yapılan çalışmaların iş sağlığı ve güvenliği alanında ilk yazılı kaynak olduğu düşünülmektedir. Bu nedenle, Heredot'un iş sağlığı ve güvenliği alanında ilk önemli araştırmaları yaptığını kabul etmek yanlış olmayacaktır. Ayrıca, Heredot işçilerin nasıl daha sağlıklı olabileceği konusu üzerine düşünmüş, bunun için işçilerin daha iyi beslenmesi gerektiğini ifade etmiştir. Bu nedenle, Heredot işçilerin enerji arttıran besinler alması gerektiğini, zira düzgün beslenmenin işçilerin verimini de arttıracağını savunmuştur (Çiçek ve Öçal, 2016, s. 111). Bunun yanında Antik Yunan döneminde yaşamış ünlü bir tıp bilgini olan Hipokrat madenlerde çalışan işçilerin sağ lı̆̆ına zarar veren etkenleri araştırırmış ve işçilerin çalışırken kurşun zehirlenmesine yakalandıği tespitinde bulunmuştur (Çetindağ, 2010, s. 1). Bu nedenle, Hipokrat işçi sağlığına zarar veren etkenleri araştırırken, işçilerin yaptıkları işler nedeniyle sağlıklarının bozulabileceği tespitinde bulunmuştur. Ancak, Antik Yunan döneminde iş sağlığı ve güvenliği alanında yaşanan gelişmeler Hipokratın yaptığı araştırmalar ile sınırlı kalmamıştır (Aktuna, 2017, s. 12). Zira Nicander, Hipokrat tarafından yapılan çalışmaları geliştirerek işçilerin zararlı etkenlerden korunabilmesi için alınması gereken tedbirler üzerinde de durmuştur. Plini ise işçilerin tozlardan korunabilmesi için başlarına torba geçirebileceklerini ifade etmiştir (Çiçek ve Öçal, 2016, s. 112).

Roma döneminde de iş sağlığı ve güvenliği açısından madenlerde önemli gelişmeler yaşanmıştır. Zira, Roma Devleti madencilik faaliyetlerini sürdürebilmek ve maden üretimini arttırabilmek amacıyla kölelerin beden gücünden oldukça fazla yararlanmıştır. Ayrıca, Roma döneminde madenlerde çalıştırılan kölelere çoğu zaman herhangi bir ücret de ödenmemiştir. Bu nedenle, kölelerin madenlerde ücretsiz çalıştırılmasına yönelik çeşitli kanuni düzenlemeler de yapılmıştır (Turhan, 2016, s. 17). Bunun yanında, Roma döneminde maden üretimini artırabilmek adına madenlerde çalışan köle sayısını arttırmaya yönelik politikalar da izlenmiş ve köleler maden mühendislerinin gözetimi altında çalıştırılmıştır. Özellikle, Equites şirketleri tarafından işletilen madenlerde 40,000 kadar kölenin çalıştırılması dikkat çeken bir gelişmedir (Sertaş, 2010, s. 72). Ancak, tarihte ilk defa Roma Devleti'nde maden işçilerine yönelik iş sağlığı ve güvenliği alanında hukuki düzenlemelerin yapıldığı kabul edilmektedir. Ayrıca, Roma döneminde bir hekim olan Dioscorides Pedanius, "İlaç Bilgisi Üzerine" (Peri Hyles latrikes) adını taşıyan eserinde ilaçları kategorize etmiştir. Aynı şekilde bu dönemde yaşamış Juvenal ise; işçilerin ayaklarında görülen varisler ile demircilerin karşılaştıkları göz hastalıklarına 
yönelik olarak birtakım tespitler ortaya koymuştur. Bunun yanında Pliny, kurşun ve kükürdün işçiler açısından olumsuz etkilerini inceleyerek, ilk kişisel koruyucu donanım olan deri maskelerini tasarlamıştır (Çetindağ, 2010, s. 1). Dolayısıyla, Roma döneminde de iş sağlığı ve güvenliği alanında oldukça önemli gelişmeler yaşanmıştır. Ayrıca yaşanan tüm bu gelişmeler ileride Avrupa'da iş sağlığı ve güvenliği alanında yaşanacak gelişmelere ve madenlerde uygulanacak iş sağlığ1 ve güvenliği politikalarına da zemin hazırlamıştır (Baycık, 2006, ss. 37-38). Zira, Avrupa'da Rönesans ve Reform döneminde modern anlamda iş sağlığı ve güvenliğinin temeli olarak kabul edilebilecek gelişmeler yaşanmıştır. Paracelsus, ilk iş hekimliği kitabı olarak kabul edilen "De Morbis Metallici" adlı eserinde madenlerde çalışan işçilerin madenlerde çalışmaları nedeniyle cıva ve kurşun zehirlenmelerine yakalandıklarından bahsetmiştir. Agricola, "De Re Metallica" eserinde, jeoloji ve madencilik alanında önemli bilgiler vererek maden ocaklarında oluşan tozun kalkması için havalandırmaların yapılması gerektiğinden bahsetmiştir. Bunun yanında yazar iş ve sağlık arasındaki bağlantıyı da ortaya koymuş ve bazı tavsiyelerde bulunmuştur (Çiçek ve Öçal, 2016, s. 113). İlaveten, iş sağlığ1 ve güvenliğinin kurucusu olarak bilinen İtalyan hekim Bernardino Ramazzini "De Morbis Artificum Diatriba (İşçi Hastalıkları Üzerine Konuşmalar)" adını taşıyan eserinde meslek hastalıkları ile yapılan işler arasındaki ilişkiyi ortaya koymuştur. Bunun yanında yazar işyeri hekimlerinin sahip olmaları gereken nitelikleri de ele almıştır. Ancak, o dönemde iş sağlığı ve güvenliği için harcama yapılması, bunu zorunlu kılan hukuki bir düzenlemenin bulunmaması nedeniyle gereksiz görülmüş ve Ramazzini'nin düşünceleri tam anlamıyla hayata geçirilememiştir (Baycık, 2006, s. 38). Zira, bu dönemde iş sağlığ 1 ve güvenliği açısından madenlerde birçok sorun yaşanmıştır. Örneğin, bu dönemde İngiltere'de maden işçileri uzun saatler madenlerde çalıştırılmış ve madenlerde sağlıksız bir ortam bulunmaktadır. Ayrıca, bu dönemde madenlerde zorunlu çalıştırma sistemi de uygulanmıştır (Özveri, 2015, s. 26-29).

18. yüzyılın ikinci yarısında başını İngiltere'nin çektiği Batı Avrupa ülkelerinde başlayan sanayileşme süreci, Batı Avrupa' da ekonomik ve teknik açıdan önemli gelişmelerin yaşanmasına zemin hazırlamıştır (Çelik vd., 2017, s. 3). Ayrıca, bu dönemde ekonomik nedenlerle madenlerde üretimi arttırmaya yönelik çeşitli politikalar izlenmiştir. 19. yüzyılda ise, kömür stratejik bir konuma oturmuştur. Başta demir-çelik endüstrisi olmak üzere birçok sektörde kömür kullanılmış ve kömürün 1sıtıcı özelliğinden faydalanılmıştır. Kömürden 
güç alan buhar makinelerinin de gelişmesi ile birlikte kömüre olan bağımlılık artmıştır (Bozoğlan, 2010, ss. 3-4). Bu nedenle, sanayileşme süreci ile birlikte maden işçilerinin çalışma şartları da ağırlaşmış ve madenlerde iş sağlığı ve güvenliği sorgulanır hale gelmiştir. Bu durumun ortaya çıkmasında sanayileşme ile birlikte ortaya çıkan kapitalist anlayış da etkili olmuştur (Turan, 1981, s. 51).

Bu şartlar altında, sanayileşme ile birlikte sağlıksız ve kötü çalışma koşulları ortaya çıkmıştır. Bu nedenle, sanayileşme ile birlikte iş kazası ve meslek hastalıklarının görülme sıklığı da artmıştır (Kurt, 2013, s. 13). Bunun yanında, iş sağlı̆̆ 1 ve güvenliğini tehdit eden riskler çeşitlilik göstermiş ve işçiler bu risklere daha fazla maruz kalmaya başlamıştır. Örneğin, işçiler çalışırken kullandıkları araç, gereçlerden ve çalışma ortamından kaynaklanan gaza, toza veya gürültüye ya da çalışırken kullanılan makinelerden kaynaklanan risklere daha fazla maruz kalmaya başlamıştır (Yamakoğlu, 2016, ss. 25-27). Maden ocaklarında da bu sorunlar çok belirgin şekilde yaşanmıştır. Zira, maden ocaklarında birçok iş kazası yaşanmış ve çok sayıda işçi de hayatını kaybetmiştir (Baycık, 2006, ss. 38-39). Şüphesiz bu olumsuz tablonun ortaya çıkmasında

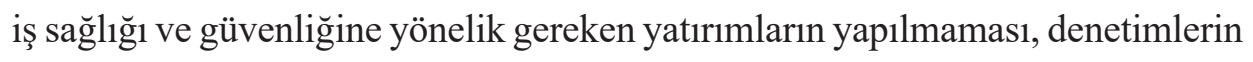
yetersiz kalması, işverenlerin iş sağlı̆̆ 1 ve güvenliğine gereken önemi vermemesi ve işverenlerin iş sağlı̆̆ ve güvenliği konusundaki bilgi eksikliği de etkili olmuştur (Karadeniz, 2012, s. 29). Bu sebeplerle sanayileşme döneminde ilk tıbbi hizmetler madencilik sektöründe özellikle de kömür madenlerinde başlamıştır Ayrıca, bu dönemde madenlerde iş kazalarını engellemeye ve iş kazası olması halinde de işçilerin beden bütünlüğünü korumaya yönelik tedbirler de alınmaya başlamıştır. Bu şekilde sanayileşme döneminde madenlerde iş sağlığı ve güvenliği açısından oldukça önemli glişmeler yaşanmıştır.

Sanayileşme döneminde işçiler genel olarak zor şartlar altında çalışmıştır. Örneğin, bu dönemde uzun çalışma saatleri önemli bir sorundur. Zira, iş sağlığ1 ve güvenliği alanında yapılan ilk yasal düzenlemelerde de bu durum göz ardı edilmemiştir (Balkır, 2012, ss. 58-59). Ancak, maden ocaklarında görülen başkaca sorunlar da bulunmaktadır. Bu nedenle, İngiliz Parlamenter Anthony Ashley Cooper, maden ocaklarında çalıştırılan kadın ve çocuk işçilere yönelik koruyucu düzenlemelerin getirilmesi gerektiğini yüksek sesle savunmuştur. Bunun yanında bir hekim olan Thomas Percival'de çocuk işçilerin çalışma saatleri ve çalışma koşullarının iyileştirilmesi gerektiği yönünde raporlar 
hazırlamıştır (Çiçek ve Öçal, 2016, s. 115). Bu gelişmelerin üzerine İngiltere'de 1842 yılında hazırlanan Kraliyet İnceleme Kurulu Raporunda, altı-on yaş arasındaki çocukların insan sağlığı açısından çeşitli zararları olan maden ocakları galerilerinde çalıştırıldığı, kadın ve genç işçilerin tehlikeli bir şekilde kömür yüklü vagonlarında çalıştırıldığı ve çalışan işçiler açısından solunum sistemine büyük zararı olan maden tozları ve maden kazalarına karşı önlem alınmadan çalıştırıldığ 1 raporlanmıştır. Çalışma koşullarının ağırlığı, sağlıksızlığ1, yetersiz beslenme, kötü barınma ve çok çalışma sonucunda özellikle çocuk ve genç işçiler "İngiliz hastalığı" olarak da bilinen raşitizm hastalığına yakalanmıştır (Baycık, 2006, s. 39).

İş sağlığı ve güvenliği önlemlerine gereken önceliğin verilmediği bu dönemde hastalıkların yanında iş kazalarının sayısı da oldukça artmıştır (Kurt, 2013, s. 13). Zira, bu dönemde yapılan araştırmalara göre maden kazalarında, her 476 maden işçisinden 1 tanesinin öldüğü şeklindedir (Baycık, 2006: 40).

Avrupa'da İngiltere dışında diğer Avrupa ülkelerinde de iş sağ lığı ve güvenliği alanında kanuni düzenlemeler yapılmıştır. Örneğin, İsviçre' de 1840, Fransa'da 1842 (Villerme Raporu), Almanya'da 1849 yılında iş sağlı̆̆ı ve güvenliği ile ilgili kanuni düzenlemeler yapılmıştır (Çiçek ve Öçal, 2016, s. 116).

Sanayileşme ile birlikte Amerika Kıtası'nda da maden işçilerinin çalışma şartları tartış1lır hale gelmiştir. Zira, 19. yüzyılda ABD'de kömüre olan bağımlılık artmış ve kömür madenlerinden oldukça fazla istifade edilmiştir (Güven, 2015: 6). Ancak, bu durum maden işçileri açısından birtakım olumsuzlukları da beraberinde getirmiştir. Bu nedenle, maden işçilerinin sağlıklarının bozulması üzerine 1850'li yılların ortalarından itibaren bu alanda birçok araştırma yapılmış ve yapılan araştırmalar sonucunda kömür tozlarının insan sağlığını bozucu etkilerini gösteren birçok veri elde edilmiştir (Özveri, 2015, s. 25). Bu şekilde, Amerika Kıtası'nda da maden işçileri açısından iş sağlığ1 ve güvenliği alanında birçok önemli gelişme yaşanmış ve bu alanda kanuni düzenlemeler de yapılmıştır (Sökmen, 2016, ss. 3-4).

Örneğin, 1872 yılında ABD'de Maden Arama Kanunu yürürlüğe girmiş ve madencilik alanında daha ileri teknikler uygulanmıştır (Topaloğlu, 2011, s. 2). İzlenen bu politikalarla birlikte, madenlerde üretimin sağliklı ve güvenli bir ortamda yapılması için önemli adımlar atılmıştır (Uluslararası Çalışma Örgütü, 2016, ss. 62-63). Bu gelişmelere rağmen madenlerde iş sağlığ 1 ve güvenliğinin 
gerektiği şekilde sağlanıp sağlanmadığı yönünde tartışmalar olmuştur. Zira, 1907 yılında Monongah Kömür Madeninde ABD’nin en büyük maden kazası yaşanmıştır ve bu kaza kayıtlara "facia” olarak geçmiştir. Yaşanan bu kazada 362 madenci hayatını kaybetmiştir. Bu kaza ile birlikte, maden ocaklarında havalandırma, çıkış tünelleri, kömür tozlarının olumsuz etkileri, maden ocağında patlama riskini ortaya çıkaran etkenler araştırılmıştır (britannica.com, 2020, 1 Ağustos). İlerleyen dönemde ABD'de maden işçilerinin yakalandığı meslek hastalıkları açısından da bazı araştırmalar yapılmıştır. Örneğin, 1919 yılında Harvard Üniversitesi'nde çalışan Alice Hamilton, bakır madenlerinin silikoz, cıva madenlerinin ise cıva zehirlenmelerine yol açabileceği tespitinde bulunmuştur (Çiçek ve Öçal, 2016, s. 116).

ABD'de yaşanan bu gelişmeler üzerine 1977 yılında Federal Maden Güvenliği ve Sağlığı Kanunu ye sonrasında 2006 yılında Maden İyileştirme ve Yeni Acil Müdahale Yasası yürürlüğe girmiştir. 2006 yılında yürürlüğe giren Yasa ile iki yönlü kablosuz haberleşme sisteminin kurulması, yer altında bulunan çalışanların takip edilebilmesi amaçlanmış ve elektronik takip sistemi oluşturulmuştur (Sökmen, 2016, ss. 3-4).

ABD, madenlerde iş sağlığı ve güvenliğinin sağlanmasında oldukça önemli mesafe kat edilmiştir. Madenlerde iş sağlığ 1 ve güvenliğinin sağlanmasında maden işçilerine eğitim verilmesi temel teşkil etmiştir. Zira, iş sağlığı ve güvenliğinin sağlanması için eğitim öncelikli olmalıdır ve işçi ile işverenin de dayanışma içinde olması gerekmektedir. Ancak, bu sistemin oturması zaman almıştır (Tiryaki, 2018, 19 Nisan).

Dünya genelinde önemli yer altı zenginliklerine sahip ülkelerden biri de Güney Afrika Cumhuriyeti olmuştur. Bu yer altı zenginlikleri Güney Afrika Cumhuriyeti ekonomisi için de önemli bir yere sahiptir (Temizok, 2018, s. 242). Bu nedenle, 20. yüzyılda Güney Afrika Cumhuriyeti'nde de madenlerde üretimin sağlıklı ve güvenli bir şekilde yapılabilmesi için birtakım kanuni düzenlemeler yapılmıştır (Sökmen, 2016, s. 7). Bu kanuni düzenlemelerin yapılmasında madenlerde yaşanan kazalar ve ölümler oldukça etkili olmuştur. Örneğin, 1960 yılında Güney Afrika'da Coalbrook kömür madeninde feci bir kaza yaşanmış ve yaşanan kazada 435 emekçi göçük altında kalmıştır. Bu elim hadise üzerine kömür madenlerinin sağlamlaştırılması ve güvenliğin sağlanması amacıyla çeşitli çalışmalar yapılmıştır. Ayrıca, göçük altında kalanlara hızlı ve etki ulaşabilmek için kurtarma ekipmanları oluşturulmuştur (Merwe, 2006, s. 858-859). 
Çin de dünya kömür madenciliğinde önemli konuma sahip olan ülkeler arasında yer almıştır. Bu nedenle, Çin'de her dönem kömür üretimi giderek artmıştır (Güven, 2015, s. 3). Ancak, bu durum madenlerde iş sağlığ 1 ve güvenliği açısından birtakım olumsuzlukların yaşanmasına neden olmuştur. Çeşitli kanuni düzenlemeler yapılmış olsa da madenlerde kazalar yaşanmaktadır. Örneğin, 2016 yılında Çin'de bir kömür maden ocağında grizu patlaması yaşanmış ve yaşanan kaza sonucu 12 madenci hayatını kaybetmiştir (mining, 2020, 27 Temmuz). Ayrıca, Çin'de 1949 yılından itibaren 26 büyük maden kazası yaşanmıştır. Bu nedenle, Çin'de madenlerde güvenlik denetimi, organizasyon oluşturulması, devlet işletme ve çalışanlar arasındaki işbirliğinin sağlanması, güvenlik kurallarının ve kanuni düzenlemelerin tamamlanması, güvenlik yatırımlarının güvenlik eğitiminin iyileştirilmesi, güvenlik tekniğinin geliştirilmesi, acil kurtarma ve ekipmanların oluşturulması açısından çeşitli adımlar atılmıştır (çalışmaortamı, 2020, 9 Ağustos). Bu gelişmeler üzerine Çin'de 2005-2018 yılları arasında iş kazası sonucu kömür madenlerinde ölen işçi oranlarında \%95'lik bir azalma yaşanmıştır. Çin'de madenlerde iş kazası sonucu yaşanan bu ölümlerin azalmasında 2000'li yılların başında iş sağlı̆̆ı ve güvenliği mevzuatında yapılan düzenlemeler, kurumsal bir kimlik kazanan bir denetim sisteminin kurulması, kaçak madenciliğe darbe vurulması ve küçük maden ocaklarının birleştirilmesi oldukça etkili olmuştur (Sökmen, 2019, ss, 29-30).

Avustralya' da da kömür madenciliği yapılırken iş sağlığı ve güvenliği esas alınmış ve bu yönde kanuni düzenlemeler yapılmıştır (Blank ve Aziz, 2009, ss. 9-10). Ayrıca Avustralya' da madenlere teknoloji de girmiştir. Bu nedenle, madenlerde iş sağlı̆̆ 1 ve güvenliği açısından önemli mesafeler kat edilmiştir. Ancak, buna rağmen maden ocaklarında yaşanan ölümler tamamen engellenmiş değildir. Örneğin, 2013 yılında Avustralya madenlerinde iş kazası ve meslek hastalıklarından kaynaklı 8 madenci yaşamını yitirmiştir (Reece, 2018, 3 Aralik).

Şili de önemli maden rezervlerine sahip ülkelerden biridir. Ancak, Şili'de daha çok bakır madenciliği yapılmaktadır. Şili tarihinde de madencilik açısından acı tecrübeler yaşanmıştır. Zira, 1945 yılında El Teniente Bakır Madeni'nde yaşanan kazada 355 madenci yaşamını yitirmiştir (whc.unesco, 2020, 30 Temmuz). Bu nedenle, Şili’de de madenlerde iş sağlığı ve güvenliği akanında önemli gelişmeler yaşanmıştır. İş sağlığı ve güvenliğine dönük kanuni 
düzenlemeler yapılmıştır. Bu doğrultuda, madenlerde kaza riskini önlemek amacıyla çeşitli adımlar atılmıştır. Özellikle, madenlerde göçük olmaması için çeşitli tedbirler alınmıştır. Zira, Şili madenlerinde göçük riski oldukça fazladır. $\mathrm{Bu}$ kapsamda göçük riskine karşı madenlerin güçlendirilmesine gidilmiş ve madenlerde yaşam odası oluşturulmuştur (Güneş, 2018, 11 Nisan).

Bu açıklamalardan hareketle, ülkeler genel olarak maden işçilerine yönelik yaptıkları kanuni düzenlemelerde, iş sağlığı ve güvenliği konusunda düzenleme yapma ihtiyacı duymuştur (Turhan, 2016, s. 31). Ayrıca, ülkeler madenlerde iş sağlığı ve güvenliğini sağlamak için çeşitli yöntemler uygulamıştır. İzlenen bu yöntemler gelişmiş ülkelerde maden kazalarının azalması açısından büyük katkı sağlamışsa da, denetim mekanizması gelişmemiş ya da denetim mekanizması yetersiz kalan ülkelerde madenlerde iş sağlığı ve güvenliğinin tesis edilmesi açısından bu şekilde olumlu bir tablo ortaya çıkmamaktadır (çalışmaortamı, 2020, 9 Ağustos).

\section{Türkiye'de Maden İşçilerini İlgilendiren İş Sağlığı ve Güvenliği Alanında Yaşanan Gelişmeler}

\section{Osmanlı Devleti Döneminde Yaşanan Gelişmeler}

Osmanlı Devleti'nde madenlerin çıkartılması ve işletilmesi açısından ekseriyetle dini kaideler uygulanmıştır. Bu nedenle, şer'i hükümler doğrultusunda madenler işletilip çalıştırılmıştır (Kaştan, 2016, ss. 8-10). Bu madenlerin işletilmesi ve çalıştırılması açısından çok sayıda işçiye ihtiyaç duyulmuştur. $\mathrm{Bu}$ ihtiyaç zorunlu çalıştırma sistemi kullanılarak karşılanmıştır. Osmanlı Devleti'nde madenlerde ve orduda genellikle zorunlu çalışma sistemi uygulanmıştır. Osmanlı Devleti'nde çalışma hayatında genel olarak, kendi isteğiyle çalışan yerli işçiler, yabancı işçiler, askerler, esirler, köleler ve zorunlu çalışanlar bulunmaktadır. Bu sistem içinde en çok zorunlu çalıştırılanlar madenlerde istihdam edilmiştir (Güven, 2015, ss. 23-24). Bunun yanında, Osmanlı Devleti'nde dini esaslara dayanarak kurulmuş zaviye teşkilatı, ahilik teşkilatı, ve lonca teşkilatı gibi kuruluşlar da maden işçilerine birçok yönden fayda sağlamıştır (Akyiğit, 2016, ss. 41-42). Örneğin lonca teşkilatı, hastalık, malullük, yaşlılık, kaza, ölüm gibi konularda oluşan mağduriyetlerin giderilmesinde önemli bir rol oynamıştır. Özellikle, loncalar içinde bulunan teavün sandıkları kaza geçiren iş göremez hale gelen veya hasta olan üyelerine 
bu yardımları yapmıştır (Süzek, 2017, s. 10). Ancak, Osmanlı Devleti’nde maden işçilerini ilgilendiren asıl önemli gelişmeler Tanzimat Dönemi ile birlikte yaşanmıştır. Ayrıca, bu dönemde iş sağlı̆̆ güvenliği ve sosyal güvenlik alanında oldukça önemli gelişmeler yaşanmıştır (Şenocak, 2009, s. 425).

$\mathrm{Bu}$ dönemde maden işçilerini koruma gayesi ile birçok kanuni düzenleme yapılmıştır. Yapılan bu kanuni düzenlemeler aynı zamanda, iş sağlı̆̆ ve güvenliği alanında yapılan ilk hukuki düzenlemelerdir (Keskin, 2011, ss. 127128). Zira, çok sayıda işçinin çalıştırıldığı maden ocakları elverişli çalışma koşullarından yoksundur. Dolayısıyla, Tanzimat Döneminde sanayileşmenin getirdiği olumsuz şartlar maden ocaklarında belirgin şekilde hissedilmiştir (Mollamahmutoğlu vd., 2014, ss. 42-43).

Tanzimat Döneminde Osmanlı Devleti’nde sanayileşme hamleleri başlamıştır. Şüphesiz bu sanayileşme hamleleri maden ocaklarındaki üretimin artmasına ve işçilerin çalışma koşullarının bozulmasına neden olmuştur (Çiçek ve Öçal, 2016, s. 123). Bu nedenle, madenlerde iş sağlığı ve güvenliğinin oluşturulması için mevzuat çalışmaları hızlanmıştır. Ayrıca, Tanzimat Döneminde Osmanlı Devleti, madencilik açısından da Avrupa ülkelerinin gerisinde kaldığını fark etmiş ve bu yönde de çalışmalar yapmıştır (Güven, 2015, s. 6). Bu nedenle, Tanzimat Döneminde madencilik sektöründe diğer sektörlere göre daha fazla gelişme yaşanmıştır. Zira, Osmanlı ordusunda yapılan yenilikler madenlere olan bağımlılı̆̆ı oldukça arttırmıştır (Gürbüz, 2014, ss. 7-8). Bu durum özellikle kömür madenlerinde çok sayıda işçinin istihdam edilmesine neden olmuştur. Örneğin, 1846 tarihli bir kayıtta Ereğli Kömür madenlerinde, kömür ocaklarında 1500, kömürün nakliyesinde de 300 kadar işçinin çalıştırıldığı belirtilmektedir (Kaştan, 2016, s. 6).

19. yüzyılda Osmanlı Devleti'nin donanmada ve fabrikalarda buhar gücünü kullanmak istemesi ve uzun süren savaşlar madenlerde üretimin artmasına ve çok sayıda işçinin çalıştırılmasına neden olmuştur (Koç, 2016, s. 63). Ayrıca, maden ocaklarında iş sağlı̆̆ 1 ve güvenliğine gereken önem verilmemiştir. Bunun yanında, madenlerde üretimi arttırabilmek için işçiler çoğu zaman baskı altına alınmıştır. Buna ek olarak madenlerde bazı usulsüzlükler ve ihmaller de yaşanmıştır (Günay, 2017, s. 63).

Bu gelişmeler üzerine yapılan kanuni düzenlemelerle maden işçilerine yönelik koruyucu bir politika izlenmiştir. Bu şekilde maden işçilerinin 
sanayileşmenin getirdiği olumsuzluklara karşı koymaları amaçlamıştır (Demir, 2007, s. 7). Bu kapsamda çeşitli nizamnameler yürürlüğe girmiştir. Bu kapsamda ilk olarak, Fransız Medeni Kanunu'ndan esinlenerek hazırlanan 1862 tarihli Maadin Nizamnamesi yürürlüğe girmiştir (Topaloğlu, 2003, s. 3). Ancak, bu düzenleme ile birlikte Osmanlı Devleti'nin madenlerinde Avrupalı Devletler söz sahibi olmuştur. Zira, bu düzenleme ile yabancılara Osmanlı Devleti'nde maden işletmesi açma hakkı tanınmıştır (Turhan, 2016, s. 51). Ayrıca, yabancıların açtığı maden işletmelerinde çalışan işçiler oldukça kötü şartlar altında çalıştırılmıştır. Lakin, Nizamnamede işçiler açısından lehe olan birtakım düzenlemeler bulunmaktadır (Öztoprak, 2016, s. 39). Örneğin, Nizamnamede işçilerin kendi rızalarıyla madenlerde çalıştırılabileceği hükme bağlanmıştır. $\mathrm{Bu}$ şekilde, zorla çalıştırma ve angarya yasaklanmıştır. Buradan hareketle Nizamnamenin işçilere bir sosyal koruma getirdiğini söylemek mümkün bulunmaktadır (Akyiğit, 2016, s. 42).

1867 yılında ise, Dilaver Paşa Nizamnamesi yürürlüğe girmiştir. Bu Nizamnamenin hazırlanmasında Osmanlı Devleti’nde o dönemde uygulanan kömür politikalarının etkisi olmuştur (Şenocak, 2009, ss. 425-426). Bu nedenle, daha çok kömür çıkartabilmek için işçilerin sosyal ve ekonomik yönden desteklenmesi amaçlanmıştır. Bu amaç doğrultusunda 8 Mayıs 1867 tarihinde Dilaver Paşa Nizamnamesi (Ereğli Maadin-i Hümayun Teamülnamesi) yürürlüğe girmiştir. Dilaver Paşa Ereğli Kömür Havzası'nda edindiği bilgiler ve kazandığ1 tecrübeler sonucu bu nizamnameyi hazırlamıştır (Kaştan, 2016, s. 12).

Yaklaşık 100 maddesi bulunan Dilaver Paşa Nizamnamesi padişahın onayından geçmemiş olmasına karşın, Ereğli Kömür Havzası'nda uygulanmak istenmiştir. Ayrıca, Dilaver Paşa Nizamnamesi Osmanlı Devleti'nde çalışma hayatı açısından da oldukça önemli düzenlemeler getirmiştir (Koç, 2016, ss. 68-69). Madenlerde çalışan işçilerin hakları ele alınmıştır. Zira, Nizamnamede maden işçilerini koruyucu nitelikte birtakım düzenlemeler bulunmaktadır (Korkmaz ve Alp, 2016, s. 28). Bu yönüyle Dilaver Paşa Nizamnamesi özel işçi gruplarına yönelik bir düzenlemedir. $\mathrm{Bu}$ nedenle, Dilaver Paşa Nizamnamesinde iş sağlığı ve güvenliği açısından işçileri koruyucu hükümler getirilmiştir (Dmeircioğlu ve Centel, 2016, s. 25). Buna göre, işçilerin geceleri korunması için maden ocaklarında işçi koğuşlarının yapılacağı, günlük fiili çalışma süresinin 10 saat olacağı düzenlenmiştir. İlaveten işçilere dinlenme sürelerinin verilmesi gerektiği de düzenlenmiştir (Çiçek ve Öçal, 2016, s. 124). 
İşçilere hafta tatili verilmemekle birlikte, Müslümanlar dini bayramlarda, Hiristiyanlar ise paskalya bayramında izin kullanabilmektedir. Ayrıca, madenlerde doktor bulunması gerektiği, hastalığı tedavi edilebilecek olan hastaların hemen orada tedavi edilmesi, ağır hasta olanların ise köyüne gönderilmesi gerektiği düzenlenmiştir (Koç, 2016, s. 69). Nizamnamede hastalıktan söz edilmekle birlikte, iş kazasından çok fazla söz edilmemiştir. İş kazası olması halinde ne gibi tedbirlerin uygulanacağından bahsedilmemiştir. Ancak, Nizamnamede maden işçilerinin çalışma şartları ayrıntılı şekilde düzenlenmiştir (Gürbüz, 2014, s. 6). Bunun yanında, maden işçilerini etkileyebilecek başkaca konular da düzenlenmiştir. Örneğin, kömür ocaklarının oluşumu, yönetimi, işletilme şekli gibi konular düzenlenmiştir. Nizamname ile bölgede çalışabilecek erkekler kayıt altına alınmıştır (Özveri, 2015, s. 26). Nizamnamede ücretli iş mükellefiyeti ile ilgili düzenlemeler de bulunmaktadır. Ancak, Dilaver Paşa Nizamnamesinde bir denetim mekanizması oluşturulmamıştır (Ünlütürk ve Ulutaş, 2015, s. 331). Bu nedenle, Dilaver Paşa Nizamnamesi işlevsiz hale gelmiştir. Dolayısıyla, maden işçileri için hazırlanan bu Nizamname hayata geçirilememiş ve uygulanamamıştır (Çelik vd., 2017, s. 7).

Bu doğrultuda, 1810 Fransız Medeni Kanunu esas alınarak, doksan maddeden oluşan 1869 tarihli Maadin Nizamnamesi yürürlüğe girmiştir. 1869 tarihli Maadin Nizamnamesi ile Dilaver Paşa Nizamnamesinin eksik kalan yönleri tamamlanmak istenmiştir (Günay, 2017, s. 64). Ayrıca, 1869 tarihli Maadin Nizamnamesi, Dilaver Paşa Nizamnamesinden farklı olarak tüm ülke çapında uygulanmak amaciyla yürürlüğe konulmuştur. 1869 tarihli Maadin Nizamnamesi madenlerde mecburu çalışma uygulamasını kaldırmıştır (Demir, 2007, ss. 7-8). Mecburu çalışmanın kaldırılması için valilere ve mühendislere de sorumluluk yüklenmiştir. Zira, 61. maddede ocaklarda zorunlu çalışma uygulaması yasaklanmıştır (Kaştan, 2016, s. 12). Dolayısıyla, madenlerde angarya çalışma sistemi tümüyle terk edilmiştir. Bunun yerine ücretli çalışma sistemi benimsenmiştir (Korkmaz ve Alp, 2016, s. 28).

1869 tarihli Maadin Nizamnamesinde iş kazasına uğrayan işçiye, işçinin ailesine işverenin tazminat ödemesi gerektiği düzenlenmiştir. Ayrıca, iş kazasının olmasında kusurlu işverenin para cezası ödemesi gerektiği belirtilmiştir (Çiçek ve Öçal, 2016, s. 125). Bu nedenle, 1869 tarihli Nizamname işvereni madende iş kazalarının yaşanmaması için gerekli tedbirleri almakla yükümlü 
tutmuştur. Bu şekilde Nizamname iş kazası olması halinde işverenin hukuki sorumluluğuna gidileceğini düzenlemiştir (Özveri, 2015, s. 28). Bunun yanında, Nizamname iş kazalarının önlenmesi açısından madenlerdeki mühendislere de sorumluluk yüklemiştir. Buna göre, mühendislere madenlerde gereken önlemleri alma yükümlülüğü yüklenmiştir. Ayrıca, Nizamname mühendislere iş kazalarının önlenmesi için gerekli malzemeleri idareden isteme yetkisi de vermiştir. İlaveten Nizamnamede madende kaza yaşanması halinde kazaların idareye bildirilmesi, madenlerde doktor ve eczane bulundurulması gibi konular da düzenlenmiştir. Bu bağlamda 1869 tarihli Maadin Nizamnamesinde iş kazası olması halinde alınması gereken önlemler ile kaza olması halinde hangi miktarda tazminat ödeneceği düzenlenmiştir. Buna göre, kazaya uğrayan işçinin ailesine de mahkemece belirlenen tazminatın ödenmesi gerekmektedir. Ayrıca, kazanın olmasında ihmali olanların ve sorumluların para cezası ödemesi gerektiği de düzenlenmiştir (Günay, 2017, s. 65). Dolayısıyla, iş kazasının önlenmesi için gerekli önlemlerin alınması ve iş kazası olması halinde de gecikilmeden iş kazasının yetkili makamlara bildirilmesi gerektiği Nizamname ile düzenlenmiştir. Bu şekilde 1869 tarihli Maadin Nizamnamesi iş sağlı̆̆ ve güvenliği açısından oldukça önemli düzenlemeler getirmiştir (Güzel vd., 2016, s. 24). 66. maddede madenlerde doktor ve ilaç bulundurmak zorunlu tutulmuştur. Bu şekilde her madende bir eczanenin bulunması amaçlanmıştır (Kaştan, 2016, s. 13). Dolayısıyla, Nizamnamede madenlerde iş sağlığı ve güvenliği açısından oldukça önemli düzenlemeler getirilmiştir. Ancak, 1869 tarihli Maadin Nizamnamesi zamanla madenlerde iş sağlığı ve güvenliği alanında oluşan ihtiyaçları karşılama noktasında yetersiz kalmıştır (Çelik vd., 2017, s. 8). Bu nedenle, madenlere yönelik iş sağllğı ve güvenliğine dönük kanuni düzenlemeler devam edilmiştir. Bu şekilde maden işçilerinin daha sağlıklı ve güvenli bir ortamda çalıştırılması amaçlanmıştır (Özveri, 2015, ss. 29-30). Bunun üzerine 1887 tarihinde doksan iki maddeden oluşan madenlerle ilgili bir Nizamname yürürlüğe girmiştir. Nizamnamede maden kazalarının önlenmesi için çeşitli yaptırımlar öngörülmüştür. Buna göre, kötü idare veya teknik yetersizlik nedeniyle madende kaza olması halinde para cezası kesileceği düzenlenmiştir. Bu dönemde 1906 yılında bir Nizamname daha yürürlüğe girmiştir (Karakoç, 2014, s. 18). 1906 tarihli Nizamname, Cumhuriyet döneminde de bir süre yürürlükte kalmıştır. Gerek 1887 tarihli Nizamnamede, gerek 1906 tarihli Nizamnamede işçilerin kendi rızalarıyla çalıştırılması gerektiği esasa bağlanmıştır (Gürbüz, 2014, s. 7). 
Osmanlı Devleti'nde, işçi sağlığı ve iş güvenliği alanında yapılan ilk kanuni düzenlemelerde maden işçileri hedef alınmıştır. Bu şekilde maden işçilerinin çalışma şartları iyileştirilmek istenmiştir. Ancak, yapılan kanuni düzenlemeler uzun ömürlü olmamakla birlikte, yapılan bu kanuni düzenlemeler uygulamaya da tam anlamıyla yansımamıştır (Özveri, 2015, ss. 17-24). Zira, bu mevzuat çalışmalarında iş sağlığ 1 ve güvenliği açısından maden işçilerini ilgilendiren konular ele alınmakla birlikte, bu mevzuat çalışmalarında sistematik bir yol izlenememiştir. Ayrıca, çalışma koşullarında görülen olumsuzluklar da devam etmiştir. Bu nedenle, 1908 yılında II. Meşrutiyet'in ilan edilmesi ile birlikte işçilerin çalışma şartları sorgulanır hale gelmiştir (Çelik vd., 2017, s. 9). Özellikle maden ocaklarının iş sağlığı ve güvenliği açısından yetersiz olması, maden işçilerinin ağır şartlar altında çalışması işçilerin harekete geçmesini tetiklemiştir. Örneğin, 1908 yılında Ereğli kömür madenlerinde büyük çapta bir grev hareketi olmuş ve çok sayıda işçi bu greve katılmıştır (Kaştan, 2016, s. 17). Bu nedenle, Meşrutiyet dönemi, maden ocaklarının iş sağlığı ve güvenliği açısından yetersiz kaldığı, ağır çalışma koşullarının uygulandığı bir dönem olmuştur. İlerleyen dönemde de bu tablo değişmemiştir (Korkmaz ve Alp, 2016, s. 28). Zira, I. Dünya savaşı döneminde Osmanlı Devleti'nin kömür ihtiyacının artması üzerine yeni maden ocakları açılmış ve maden ocaklarındaki kömür üretimi de arttırılmıştır. Bu nedenle, maden ocaklarında iş sağlı̆̆ 1 ve güvenliği açısından birçok olumsuzluk yaşanmıştır. Zira, bu dönemde birçok grev hareketi ortaya çıkmıştır. Örneğin, 1909-1914 yılları arasında çeşitli bölgelerde birçok madenci greve gitmiştir (Koç, 2016, ss. 71-72).

\section{Milli Mücadele Dönemi}

Milli Mücadele döneminde de (1921-1923) maden işçilerine yönelik kanuni düzenlemeler yapılmıştır. Bu şekilde Büyük Millet Meclisi uygulama alanı Zonguldak Ereğli Kömür bölgesi ile sınırlı olan 114 sayılı ve 151 sayılı Kanunları kabul etmiştir (Demircioğlu ve Centel, 2016, s. 26).

28 Nisan 1921 tarihinde Büyük Millet Meclisi 114 sayılı Kanunu yürürlüğe koymuştur. Diğer adı “Kömür Tozlarına İlişkin Kanun” olan 114 sayılı Kanun ile, kömür tozlarının satışından elde edilen paraların işçilerin ihtiyaçlarına harcanması amaçlanmıştır. Buna göre, kömür tozlarından elde edilen paraların Ziraat Bankası'nda amele heyeti adına açılan bir hesaba yatırılması kararlaştırılmıştır (Akyiğit, 2016, s. 42). 
Bu dönemde maden işçilerinin iş sağlığı ve güvenliği açısından durumunu değerlendirmek üzere, Ereğli Kömür Havzası'nda birtakım incelemeler de yapılmıştır (Topaloğlu, 2011, ss. 3-5). Örneğin, bu dönemde Celal Bayar işçilerin çalışma koşullarının elverişsiz olduğunu, kanunların burada uygulanmadığını, maden işçilerinin angarya çalışmaya zorlandığını, işçilerin yeterince beslenemediğini, klyafetlerinin de düzenli şekilde temin edilmediğini raporlamıştır. Bu gelişmelerin üzerine diğer adı "Ereğli Havzai Fahmiyesi Maden Amelelerinin Hukukuna Müteallik Kanun” olan 151 sayılı Kanun’un hazırlıkları başlamıştır. 10 Eylül 1921 tarihli 151 sayılı Kanun, iş sağlığı ve güvenliği açısından önemli düzenlemeler getirmiştir (Korkmaz ve Alp, 2016, s. 28). Ancak, 151 sayılı Kanun sadece belli işçi grupları için koruyucu nitelikte düzenlemeler getirmiştir. Zira, 151 sayılı Kanun sadece Ereğli Kömür Havzası'nda çalışan işçileri ele almıştır. Bu kapsamda, 151 sayılı Kanunda madenlerde asgari çalışma yaşı, çalışma süreleri, iş sağlığ ve güvenliğine yönelik alınması gereken önlemler, iş kazası halinde sorumluların tazminat yükümlülügü ve cezalandırılması gibi konular düzenlenmiştir (Süzek, 2017, s. 10). Buna göre, maden işçilerinin günlük çalışma süresi 8 saat olarak belirlenmiştir. Ancak, tarafların anlaşarak günlük çalışma süresini 8 saattin üzerine çıkartmalarına da imkan tanınmıştır (Özveri, 2015, s. 32). Ayrıca, işveren fazla çalışma ücretini yüzde yüz zamlı ödemek şartıyla işçilere fazla çalışma yaptırtabilmektedir. İlaveten çalışma hayatımızda asgari ücret uygulaması ilk defa bu kanunla düzenlenmiştir. Madenlerde çalışma yaşı ise 18 olarak belirlenmiş, madenlerde zorla çalıştırma sistemi de yasaklanmıştır. Buna ek olarak. işverenin kusuru nedeniyle iş kazası geçiren işçinin ölmesi halinde, işverenin iş̧̧inin ailesine tazminat ödemesi gerekmektedir. İşverenin hastalanan ya da kazaya uğrayan işçileri de tedavi ettirme yükümlülüğü bulunmaktadır (Koç, 2010, s. 72). Bu nedenle, işverenin madenin olduğu yerde hastane, eczane ve hekim bulundurması gerekmektedir. Ayrıca, maden ocağında sağlık ve güvenlik koşullarını sağlamayan maden işletmelerinin de ruhsatları iptal edilmekte ve imtiyazları da kaldırılmaktadır (Çiçek ve Öçal, 2016, s. 125). Dolayısıyla, 151 sayılı Kanun maden işçilerini koruyucu birçok düzenleme getirmiştir. Ayrıca, 151 sayılı Kanun getirdiği bu düzenlemelerle ülkemizde sosyal sigorta ile ilgili hükümler içeren ilk hukuki düzenleme niteliği de taşımaktadır (Güzel vd., 2016, s. 25; Şenocak, 2009, s. 425).

Ulusal tarihimizde Milli Mücadele döneminde maden işçilerine yönelik iş sağlığ 1 ve güvenliği alanında önemli gelişmeler yaşanmıştır. Bu dönemde 
Cumhuriyet ilan edilmemiş olmasına ve Ulusal Kurtuluş Savaşının zor şartlarına karşın maden işçilerini ilgilendiren düzenlemeler yapılmıştır (Çelik vd., 2017, s. 26). Bütün işçileri kapsayan düzenlemelerin yapılması düşünülmüşse de, her iş alanı ve iş bölgesi için ayrı ayrı düzenlemelerin yapılmasının özellikle geri kalmış iş alanları için daha faydalı olacağı düşüncesi benimsenmiştir. Bu nedenle, uygulama alanı kömür maden ocakları ile sınırlı olan kanuni düzenlemeler yapılmıştır (Demir, 2007, s. 8). Ancak, yapılan bu kanuni düzenlemeler maden ocaklarında görülen olumsuzlukların ortadan kalkması için yerterli olmamıştır. Bu dönemde de maden ocaklarında birtakım sıkıntılar yaşanmıştır. Örneğin, bu dönemde de maden ocaklarında zorunlu çalışma sistemi uygulaması görülmüştür (Makal, 2005, s. 72).

\section{Cumhuriyet Dönemi}

Cumhuriyet'in ilanıyla birlikte, sanayileşme hamleleri hız kazanmış ve bu alanda çeşitli adımlar atılmıştır. Bu amaç doğrultusunda İzmir İktisat Kongresi'nin toplanması yönünde bir karar alınmıştır (Demircioğlu ve Centel, 2016, s. 27)). Bu şartlar altında 17 Şubat 1923 - 04 Mart 1923 tarihleri arasında İzmir İktisat Kongresi toplanmış, Kongre'de Zonguldak Kömür Havzası'nda çalışan maden işçilerinin yaşadığı olumsuzluklar da göz ardı edilmemiştir. Zira, Kongre boyunca Zonguldak Kömür Havzası'nda yaşanan sorunlar ele alınmış ve madenlerin de millileştirilmesi yönünde bir karar alınmıştır (Öztoprak, 2015, s. 39). Bu dönemde iş hayatını ilgilendiren hukuki düzenlemelere de devam edilmiştir. Yapılan bu düzenlemeler doğrudan maden işçilerine yönelik olmayıp, genel nitelikte düzenlemeler olmakla birlikte, madenlerde çalışan işçileri de ilgilendirmektedir. Örneğin, 1924 yılında 394 sayılı Hafta Tatili Hakkında Kanun, 1925 yılında 2739 sayılı Ulusal Bayram ve Genel Tatiller Hakkında Kanun ve 1926 yılında 818 sayılı Borçlar Kanunu yürürlüğe girmiştir. Bu dönemde ulusal bir iş kanununun yürürlükte olmaması nedeniyle bir genel kanun olan 818 sayılı BK'nin getirmiş olduğu düzenlemeler iş hayatı açısından da büyük önem taşımaktadır. Bu kanunda işçi işveren arasındaki ilişki hizmet akdi kapsamında düzenlenmiş olup, BK'de iş sağlığı ve güvenliği konusu da düzenlenmiştir. BK'nin 332. maddesinde iş sağlığ1 ve güvenliği konusu düzenlenmiş olup, işverenin işçinin maruz kalabileceği tehlikelere karşı gerekli tedbirleri alması gerektiği, aksi halde işverenin işçinin uğradığ zararları tazminle yükümlü olduğu düzenlenmiştir. 
818 sayılı BK'nin 332. maddesinde iş sözleşmesi ve iş ilişkisinin niteliği gereği hakkaniyet çerçevesinde işverenin kendisinden beklenen önlemleri alması gerektiği düzenlenmiştir. Ancak, 818 sayılı BK'nin genel bir kanun olması nedeniyle BK' de iş sağlı̆̆ 1 ve güvenliği ile ilgili ayrıntılı düzenlemeler bulunmamaktaydı. Ayrıca, bu dönemde BK dışında iş hayatını ilgilendiren 394 sayılı Hafta Tatili Hakkında Kanun ve 2739 sayılı Ulusal Bayram ve Genel Tatiller Hakkında Kanun gibi düzenlemeler yapılmış olmasına karşın, bu düzenlemelerin maden işçilerine yönelik olumlu bir etkisi olmamıştır. Zira, bu dönemde maden ocaklarında birçok eksiklik görülmektedir ve yasalara uygun hareket edilmemektedir. Bunun yanında, maden işçilerine yönelik yasalardaki hükümlere de riayet edilmemektedir. Maden ocaklarında 18 yaşından küçüklerin çalıştırılması yasak olmasına karşın, bu durum bir gelenek halini almış 18 yaşından küçüklerin babalarıyla madenlerde çalıştırılması uygulamasına devam etmiştir (Özveri, 2015: 31-36).

Bu dönemde yaşanan önemli bir gelişme de 1930 yılında 1593 sayılı Umumi Hıfzıssıhha Kanunu'nun yürürlüğe girmesi olmuştur. Umumi Hıfzıssıhha Kanunu ile birlikte, iş hayatında kadın ve çocukların korunması, 50'den fazla işçi çalıştıran işyerlerinin hekim bulundurması, belli büyüklükteki işyerlerinde revir ya da hastanenin yapılması gibi yükümlülükler düzenlenmiştir. Umumi Hıfzıssihha Kanunu'nun 173. maddesinden 180. maddesine kadar olan hükümlerde iş sağlığı ve güvenliği ile ilgili düzenlemeler de bulunmaktadır. Bu nedenle, Umumi Hıfzıssıhha Kanunu'nda maden işçilerini ilgilendiren düzenlemeler de bulunmaktadır. Umumi Hifzıssıhha Kanunu madde 173/f-1 hükmünde on iki yaşının altındaki çocukların maden işyerlerinde işçi ve çırak olarak çalıştırılmasının yasak olduğu düzenlenmiştir. Ayrıca, Umumi Hıfzıssıhha Kanunu'nda 12 yaşından küçük çocukların fabrika ve imalathanelerde çalıştırılamayacağını, 12-16 yaş arasındaki çocukların gece döneminde saat 20'den sonra çalıştırılmasının yasak olduğunu da düzenlemiştir. 18 yaşından küçük çocukların kahve, gazino gibi yerlerde çalıştırılması yasaklanmıştır. Bu şekilde Umumi Hıfzıssıhha Kanunu çocukları koruma amacıyla hareket etmiştir (Mollamahmutoğlu vd., 2014, s. 46). Bunun yanında, Umumi Hıfzıssıhha Kanunu'nda maden işçilerini ilgilendiren başkaca düzenlemeler de bulunmaktadır. Buna göre, Umumi Hıfzıssıhha Kanunu, madenlerde günlük çalışma süresini 8 saat olarak belirlemiştir. Ayrıca, Umumi Hıfzıssıhha Kanunu maden işçisi olsun ya da olmasın tüm sektörlerde işçilerin gece döneminde gece çalışma süresini 8 saat olarak belirlemiştir. Bu şekilde gece hizmetleri ile 
yer altı işlerinde çalışan işçilerin günlük çalışma süresi 8 saat olarak düzenlenmiştir. Buna ek olarak, hamile kadınların doğumdan önce 3 aylık dönemde ağır işlerde çalıştırılması yasaklanmış, doğum yapan kadınlara da doğumdan sonraki 6 aylık dönemde yarımşar saatlik emzirme iznin verilmesi gerektiği hükme bağlanmıştır.

Bu dönemde bir iş kanunun bulunmaması nedeniyle, 1924, 1925, 1927, 1929, 1932 yıllarında yasa tasarıları hazırlanmış, ancak bu tasarılar da hayata geçirilememiş ve kadük kalmıştır. Tasarılar dönemi olarak da adlandırılan bu dönemde maden işçilerinin çalışma şartları ve madenlerde uygulanan iş sağlı̆̆ ve güvenliği yöntemleri de sıklıkla tartışılmıştır. Bu nedenle, 1932 Yasa Tasarısı hazırlanırken Ereğli Havza-i Fahmiye Amele Birliği’nin görüşleri dahi alınmıştır (Özveri, 2015, ss. 36-40). Ancak, bu dönemde sanayi alanında önemli gelişmeler yaşanmıştır. Devletin öncülüğünde ulusal sanayinin kurulması amaçlanmıştır. $\mathrm{Bu}$ amaçla 1934 yılında beş yıllık kalkınma planı hazırlanmış ve beş yıllık kalkınma planı doğrultusunda da bir iş kanunun hazırlanması için çalışmalar başlamıştır. Bunun üzerine, 08.06.1936 tarihinde kabul edilen 3008 sayılı İş Kanunu 16.06.1937 tarihinde yürürlüğe girmiştir(Çelik vd., 2017, ss. 10-11).

3008 sayılı Yasa özelliği itibarıyla Türkiye'de iş hayatını düzenleyen ilk iş kanunu olarak yürürlüğe girmiş ve kanunun uygulanabilmesi adına çok sayıda tüzük yürürlüğe girmiştir. 3008 sayılı İş Kanunu ile, çalışma yaşamında sürekli artan işçi ve müstahdem sayısına bağlı olarak işçi ve işveren arasındaki ilişkinin düzenlenmesi amaçlanmıştır. Ancak, 3008 sayılı İş Kanunu bir işverene bağımlı çalışan işçileri bedenen ya da bedenen ve fikren çalışan işçi şeklinde bir ayrıma tabi tutmuştur. Bu kapsamda fikren çalışması bedenen çalışmasına göre üstün olan işçiler 818 BK'ye tabi tutulmuştur.

3008 sayılı İş Kanunu'nda doğrudan maden işçilerini ilgilendiren düzenlemeler de bulunmaktadır. Örneğin 3008 sayılı İş Kanunu'nun 9. maddesinde, maden işçilerinin çalışma şartları ile ilgili düzenlemeler getirilmiştir (Günay, 2017, s. 68). Bunun yanında, 3008 sayılı İş Kanunu'nda iş sağlığı ve güvenliği konusunda da oldukça önemli düzenlemeler bulunmaktadır. Zira, iş kazası ve meslek hastalıkları 3008 sayılı İş Kanunu'nda sosyal koruma gerektiren riskler kapsamında düzenlenmiştir. Bu şekilde ilk defa bir yasada sistematik bir şekilde iş sağlığı ve güvenliği konusu ele alınmıştır. Lakin bu hükümler çok fazla hayata geçirilememiş ve uygulamaya yansımamıştır (Özveri, 2015, s. 48). 
3008 sayılı İş Kanunu'nun yürürlüğe girmesi ile birlikte, ülkemizde ilk defa iş sağlı̆̆1 ve güvenliği konusunda ayrıntılı düzenlemeler getirilmiştir. Ancak yapılan bu düzenlemeler, iş sağlığı ve güvenliği alanında ortaya çıkan sorunların çözümlenmesi noktasında tam anlamıyla ihtiyaçları karşılayamamıştır (işkanunu.com, 2020, 5 Ağustos).

1940’lı yıllarda genel olarak ülke genelinde maden ocaklarında kömür üretimi artmıştır. Bu durum maden ocaklarında birtakım olumsuzlukların yaşanmasına da neden olmuştur (Öztoprak, 2015, s. 40). Bu şartların etkisiyle 23.06.1942 tarihinde 4268 sayılı Madenlerin Aranması ve İşletilmesine Dair Kanun kabul edilmiştir. Madenlerin Aranması ve İşletilmesine Dair Kanun maden işçileri açısından da oldukça önemli düzenlemeler getirmiştir. Zira, Kanun'un 11. maddesinde madenin içinde veya dışında çalıştırılan işçilerin madende iş kazası yaşanması sonucu yaralanması halinde tazminata hak kazanacağı, kazaya uğrayan işçinin ölümü halinde de işçinin mirasçılarına tazminat ödeneceği düzenlenmiştir. Ayrıca, bu kişilerin tazminata hak kazanması açısından hata ve kusur oranına bakılmayacağı belirtilmiştir. Bunun yanında kazaya uğrayan sigortalının yaralanması halinde ödenecek tazminat miktarı ile kazaya uğrayan sigortalının ölümü ya da malul kalması halinde ödenecek tazminatın miktarı da gösterilmiştir. Ancak, maddede düzenlenen tazminat miktarları asgari tutar olarak düzenlenmiş, madende iş kazası olması halinde bu tutarlardan daha fazla bir tutarın da talep edilmesi mümkün bulunmaktadır.

$\mathrm{Bu}$ dönemde çalışma hayatına ilişkin de birtakım kanuni düzenlemeler yapılmıştır (Özveri, 2015: 51). Bu kapsamda 27.1.1939 tarih ve 2/12245 say1lı Fazla Saatlerle Çalışma Nizamnamesi, 6.11.1940 tarih ve 2/14637 sayılı Günde Ancak Sekiz Saat veya Daha Az Çalışması İcap Eden İşler Hakkında Nizamname, 5.2.1941 tarih ve 2/15156 sayılı İşçilerin Sağlığını Koruma ve İş Emniyeti Nizamnamesi, 11.10.1943 tarih ve 2/20738 say11 İş Müddetleri Nizamnamesi, 22.7.1948 tarih ve 3/7896 sayılı Ağır ve Tehlikeli İşler Tüzüğü yürürlüğe girmiştir. İkinci Dünya savaşı sonrası dönemde de iş hayatını ilgilendiren önemli gelişmeler yaşanmıştır (Süzek, 2017, s. 11).

1945 yılında Çalışma Bakanlığı kurulup, 1946 yılında Çalışma Bakanlığı'nın Kuruluş ve Görevleri Hakkında Kanun kabul edilmiştir. Ayrıca, 1945 yılında 4772 sayılı İş Kazaları ile Meslek Hastalıkları ve Analık Sigortaları Kanunu da kabul edilmiştir. 4772 sayılı Kanunda işin niteliği ve işyeri koşullarına bağlı ortaya çıkan mesleki risk olarak kabul edilen iş kazası kavramı ele alınmıştır. 
Ayrıca, meslek hastalığı kavramı da ilk kez ele alınmış ve hukuken düzenlenmiştir. Ancak, bedensel rahatsızlıklar meslek hastalığı olarak kabul edilmiş, ruhsal rahatsızlıklar meslek hastalığı olarak kabul edilmemiştir. Daha sonra, 12.8.1952 tarih ve 3/15556 sayılı Parlayıcı Tehlikeli ve Zararlı Maddelerle Çalışılan İşyerlerinde Alınacak Tedbirler Hakkında Tüzük, 28.5.1953 tarih ve 4/922 sayılı Maden İşletmelerinde Alınacak Emniyet Tedbirleri Hakkında Tüzük başta olmak üzere çeşitli düzenlemeler yapılmıştır. Ancak, bu düzenlemeler tam anlamıyla uygulamaya geçirilememiştir (Özveri, 2015, ss. 56-58). Bu dönemde doğrudan maden işçilerini ilgilendiren birtakım gelişmeler de yaşanmıştır. Örneğin, 03.03.1954 tarihinde kabul edilen 6309 sayılı Maden Kanunu 11.03.1954 tarihinde yürürlüğe girmiştir. Maden Kanunu'nun yürürlüğe girmesi ile birlikte 1906 tarihli Maadin Nizamnamesi ve Madenlerin Aranması ve İşletilmesi Hakkında Kanun yürürlükten kalkmıştır (Topaloğlu, 2011, s. 4). Ancak, 6309 sayılı Maden Kanunu bu düzenlemeleri yürürlükten kaldırmakla birlikte, işçi sağlığı, işçinin güvenliği, arazi ve işletme emniyeti gibi konuları da ele almıştır Bu şekilde madencilik faaliyetlerinin sağlıklı ve güvenli bir ortamda yapılması amaçlanmıştır (Öztoprak, 2015, ss. 40-41).

Maden işçilerini ilgilendiren birçok önemli gelişme 1960'l1 yıllarda yaşanmıştır (Akyiğit, 2016, s. 43; Süzek, 2017, s. 12). Zira, bu dönemde 1961 Anayasası yürürlüğe girmiştir. 1961 Anayasa'nda birçok maddede işçilere çeşitli haklar tanınmıştır. Buna göre, 1961 Anayasası'nda 42. maddede çalışma hakk1, 43. maddede çalışma şartları, 44. maddede dinlenme hakkı, 45. maddede ücretle adaletin sağlanması, 46. maddede sendika kurma hakk1, 47. maddede toplu sözleşme ve grev hakkı, 48. maddede sosyal güvenliğin esasları düzenlenmiştir.

1961 Anayasası, Türkiye işçi sınıfının tarihsel gelişiminde oldukça önemli bir yere sahip olmuştur. Tüm işçi kesimlerinde olduğu gibi maden işçileri de bu dönemde kötü çalışma koşullarına ve çalışma şartlarının ağırlığına bir tepki koymuştur. İşçilerde daha iyi çalışma koşulları için bir mücadele bilinci de ortaya çıkmaya başlamıştır. Bunun için bu dönemde birçok grev hareketi yaşanmıştır (Turgay, 2017, s. 255). Bu nedenle, 1961 Anayasası'nın iş sağlı̆̆ı ve güvenliği açısından maden işçilerine olumlu etkilerinin olduğunu söylemek yanlış olmayacaktır.

1961 Anayasası'nın en temel özelliklerinden biri de, sosyal güvenliğin bir insan hakk1 olarak kabul edilmesidir. Bu nedenle, Devlete de bir sorumluluk 
yüklenmiştir (Şenocak, 2009, s. 427). Bu nedenle, sosyal güvenlik alanında önemli gelişmeler olmuştur. Bu amaçla sigorta kollarına yönelik düzenlemeler yapılmış, dağınık halde olan sosyal sigorta uygulamalarında bir sistem kurabilmek amaciyla 1964 yılında 506 sayılı Sosyal Sigortalar Kanunu yürürlüğe girmiştir.

1970’li y1llarda da önemli hukuki düzenlemeler yapılmıştır. Örneğin, 1971 yılında 1475 sayılı İş Kanunu, 1973 yılında İşçi Sağlığı ve İş Güvenliği Tüzüğü yürürlüğe girmiştir. Bu düzenlemeler, iş sağlığ 1 ve güvenliği ile ilgili bugün uygulanan mevzuat hükümlerinin oluşmasında da önemli bir yere sahiptir. Zira, bu düzenlemeler bugünkü iş sağlığı ve güvenliği mevzuatımızın şekillenmesine büyük katk1 sağlamıştır (Özveri, 2015, ss. 56-58). İşçi Sağlığ1 ve İş Güvenliği Tüzüğünde işyerlerinde alınması gereken iş sağlığ1 ve güvenliğinin nasıl sağlanacağı, alınması gereken önlemler ile ilgili düzenlemeler bulunmakla birlikte, 1475 sayılı İş Kanunu'nun 73. ile 82. maddeleri arasında da iş sağlığı ve güvenliği ile ilgili düzenlemeler bulunmaktadır. Örneğin, 1475 sayılı İş Kanunu'nun 73. maddesinde işverenin işçi sağlığ 1 ve iş güvenliği için her türlü önlemi alarak, araç ve gereçleri tedarik etmesi ve uygun koşulları sağlaması gerektiği hükme bağlanmıştır. Ayrıca, 1475 sayılı İş Kanunu'nun 79. ve 80. maddelerde ağır ve tehlikeli işlerde çalışacak işçilerin ve 13-18 yaş aralığındaki çocukların işe alınırken ve işe alınmaları halinde çalışırken bu çocukların yaptıkları işlere elverişli olduklarını gösteren hekim raporu almaları gerektiği düzenlenmiştir. Bu şekilde iş sağlığı ve güvenliği açısından çocuklara yönelik de koruyucu bir anlayış benimsenmiştir (Yamakoğlu, 2016, s. 39).

İlerleyen dönemde doğrudan maden işçilerini ilgilendiren birtakım gelişmeler de yaşanmıştır. Örneğin, 1985 yılında 3213 sayılı Maden Kanunu yürürlüğe girmiştir. 3213 sayılı Maden Kanunu madencilik açısından birçok konuyu ele almıştır. 3213 sayılı Maden Kanunu maden işçilerini olumlu etkilemiştir. Zira, Maden Kanunu madenlerde aranma faaliyetlerinin ve madencilik sürecinin denetlenmesi ve maden işçilerinin kontrollü şekilde çalıştırılması amacına hizmet etmiştir (Turhan, 2016, s. 28-29).

Bu doğrultuda, 3213 sayılı Maden Kanunu genel olarak, proje, ruhsat, işletme hakk1, rödovans sözleşmeleri, harçlar ve rezerv araştırması vb. konuların yanında, iş sağlığı ve güvenliğine yönelik düzenlemeler de getirmiştir. Bu şekilde madenlerde sağlıklı ve güvenli bir ortamın oluşturulması amaçlanmıştır (Uluslararası Çalışma Örgütü, 2016, s. 69). İş sağlığı ve güvenliği alanında 
yapılan bu düzenlemelerle özellikle yoğun taş, kömür ve cevher tozu bulunan yer altı maden ocaklarında çalışma şartlarının iyileştirilmesi, iş kazaların ile birlikte, pnömokonyoz ve silikozis gibi hastalıkların önlenmesi ve işçiler için uygun çalışma koşullarının oluşturulması amaçlanmıştır (Türkiye Maden İşçileri Sendikası, 2010, s. 6).

$\mathrm{Bu}$ amaç doğrultusunda, madenlerde iş sağlığı ve güvenliğinin sağlanması açısından maden mühendislerinin madenlerde daimi teknik nezaretçi sıfatıyla çalıştırılması zorunluluğu getirilmiştir.

2000'li y1llara gelindiğinde, 2003 y1lında 4857 sayılı İş Kanunu yürürlüğe girmiştir. 4857 sayılı İş Kanunu ile birlikte, iş sağlığ 1 ve güvenliği ile ilgili çok sayıda yönetmelik kabul edilmiştir. Bu yönetmeliklerin içinde maden işçilerini ilgilendiren yönetmelikler de bulunmaktadır. Örneğin, Yeraltı ve Yerüstü Maden İşletmelerinde Sağlık ve Güvenlik Şartları Yönetmeliği, Patlayıcı Ortamların Tehlikelerinden Çalışanların Korunması Hakkında Yönetmelik, Kişisel Koruyucu Donanımların İşyerlerinde Kullanılması Hakkında Yönetmelik, İş Ekipmanlarının Kullanılmasında Sağlık ve Güvenlik Şartları Yönetmeliği, İş Sağlığı ve Güvenliği Kurulları Hakkında Yönetmelik, Çalışanları İş Sağlığı ve Güvenliği Eğitimlerinin Usul ve Esasları Hakkında Yönetmelik, Çocuk ve Genç İşçilerin Çalıştırılma Usul ve Esasları Hakkında Yönetmelik gibi birçok yönetmelik yürürlüğe girmiştir. Ayrıca, bu dönemde 4709 sayılı Kanun ve 5170 sayılı Kanun yürürlüğe girmiş ve 1982 Anayasa'sının çalışma yaşamını ilgilendiren bazı hükümlerinde değişiklikler hayata geçirilmiştir. Buna göre, 49. maddede çalışma hakkı ve ödevi, 50. maddede çalışma şartları ve dinlenme hakk1, 51. maddede sendika kurma hakk1, 53. maddede toplu iş sözleşmesi hakk1, 54. maddede grev hakk1 ve lokavt, 55. maddede ücretle adalet sağlanması, 60. 61. ve 62. maddelerde ise, sosyal güvenlik hukukuna ilişkin hükümler getirilmiştir. Bu şekilde iş hayatında işçileri koruyucu bir politika izlenmiştir (Çelik vd., 2017, s. 15).

2012 yılında, iş sağlığ 1 ve güvenliği konularını düzenleyecek bir kanun yapılması gündeme gelmiştir. Bu zamana kadar iş sağlı̆̆ 1 ve güvenliği ile ilgili çıkartılmış tüzük ve yönetmelikler uygulanmış ve bu konuya ilişkin bir kanuni düzenleme yapılmamıştır. Bu şartların etkisiyle 20.06.2012 tarihinde 6331 sayılı İş Sağlı̆̆1 ve Güvenliği kanunu yürürlüğe girmiştir. 
İSGK'nin genel olarak iş sağlığı ve güvenliği açısından maden işçilerine yönelik olumlu etkileri olmuştur. Zira İSGK, yeni bir iş sağlığı ve güvenliği anlayışını benimsemiştir. Bu anlayışa göre, işverenin maden ocağında çalışma ortamında ortaya çıkabilecek tehlike ve riskleri önceden öngörebilmesi, bu tehlike ve riskleri engellemesi, çalışma ortamını bu şekilde dizayn etmesi ve iş sağlığ 1 ve güvenliği açısından gerekli alt yapıyı kurarak yetkili personel ve elemanı çalıştırması gerekmektedir (Akpnar, 2015, ss. 198-200).

Bu doğrultuda, ülkemizde maden işçilerine yönelik iş sağlığ ve güvenliği alanında birçok hukuki düzenleme yapılmıştır. Ancak şu bir gerçektir ki, madenlerde iş sağlığı ve güvenliğinin tesis edilebilmesi için hukuki düzenlemelerin yapılması gerekli olmakla birlikte, bu hukuki düzenlemeler uygulamaya yansıdığı taktirde anlam kazanmaktadır. Zira, son on yıllık dönemde ülkemizde iş sağlığı ve güvenliği mevzuatında önemli gelişmeler yaşanmıştır. 2012 yılında İSGK kabul edilmekle birlikte, 176 sayılı ILO Sözleşmesi ve madenlerde iş sağlığı ve güvenliğine ilişkin yönetmelikler yürürlüğe girmiş̧tir. Ancak, son on y1llık dönemde madenlerde de birçok kaza yaşanmış, çok sayıda işçi hayatını kaybetmiştir. Örneğin, 2010 yılında Zonguldak Karadon'da, grizu patlaması ile 30 işçi yaşanan kaza nedeniyle ölmüştür (Türkiye Barolar Birliği İnsan Hakları Merkezi, 2014, s. 17). Ayrıca, 2014 yılında Soma maden kazası yaşanmış ve 301 madenci hayatını kaybetmiştir (Topaloğlu, 2014, s. 64). Bunun yanında, 2014 yılında Ermenek’te de bir maden kazası yaşanmış ve 18 içi hayatını kaybetmiştir (Düzgün, 2014, s. 2). Ancak, bu dönemde başkaca maden kazaları da yaşanmıştır (Ertürk, 2014, ss. 265-266). Dolayısıyla, iş sağlığı ve güvenliği mevzuatında yapılan düzenlemeler ve yaşanan gelişmeler madenlerde iş kazalarının önlenmesi için yeterli olmamaktadır. Bu kanun hükümleri uygulanmadığı sürece bir anlam ifade etmemektedir.

\section{Sonuç ve Değerlendirme}

İş sağlığı ve güvenliği, çalışanların sağlıklı bir şekilde ve güvenli bir ortamda çalışabilmesi anlamına gelmektedir. Bu nedenle, çalışanların sağlıklı ve güvenli bir ortamda çalışabilmesi için uygun bir ortamın oluşturulması gerekmektedir.

Bazı işler niteliği itibarıyla diğer işlerle mukayese edildiğinde daha riskli ve tehlikelidir. Madencilik işleri de diğer işlere göre oldukça tehlikeli ve risklidir. Madenciliğin bu denli riskli ve tehlikeli olması en çok maden işçilerini olumsuz 
etkilemektedir. Bu nedenle, tarihi süreç içinde Antik medeniyetlerde dahi maden işçilerinin ne kadar sağlıklı ve ne kadar güvenli bir ortamda çalıştığı tartışmalara konu olmuştur. Bu duruma birçok düşünür de kafa yormuş ve çeşitli önerilerde bulunmuştur. İş sağlığ ve güvenliği alanında yapılan kanuni düzenlemelerde de maden işçileri göz ardı edilmemiştir.

Tarihi süreç içinde birçok devlet maden işçilerine yönelik çeşitli politikalar izlemiş ve kanuni düzenlemeler yapmıştır. Ancak, maden işçilerini ilgilendiren asıl önemli gelişmeler Sanayi Devrimi ile başlamıştır. Bu dönemde madenlerde üretimin artmasına bağlı olarak, madenlerde çalışma koşulları da ağırlaşmış ve işçiler daha yoğun çalıştırılmıştır. Sanayileşme ile birlikte Avrupa' da birçok ülkede maden işçilerine yönelik iş sağlığı ve güvenliği alanında kanuni düzenlemeler yapılmakla birlikte, Amerika Kıtası'nda da bu alanda birçok önemli gelişme yaşanmış ve madenlerde iş sağlığı ve güvenliği alanında kanuni düzenlemeler yapılmıştır. Ancak bu kanuni düzenlemeler yapılmakla birlikte, madenlerde yaşanan hastalıkların ve ölümlerin önüne geçilememiştir.

Ülkemizde de geç başlayan sanayileşme süreci ile birlikte, madenlerde iş sağlığı ve güvenliği açısından çeşitli araştırmalar yapılmış ve birçok kanuni düzenleme yürürlüğe girmiştir. Ancak, yapılan kanuni düzenlemeler çoğu zaman hayata geçirilememiş ya da uygulanmamıştır. Örneğin, çalışma yaşı, çalışma süresi, iş sağlığı ve güvenliği tedbirleri alanında getirilen yasal sınırlamaların birçoğuna genellikle riayet edilmemiştir. Bu nedenle, yapılan kanuni düzenlemeler anlamını yitirmiştir. Ancak, 2012 yılında iş sağlığı ve güvenliği anlayışında bir değişim yaşanmıştır.

2012 y1lında İSGK'nin yürürlüğe girmesi üzerine, iş sağlığ1 ve güvenliği açısından önleyici ve koruyucu bir sistemin kurulması amaçlanmıştır. Bunun için iş kazası ya da meslek hastalığı yaşanmadan en baştan tedbir alınması gerektiği kabul edilmiştir. Bunun için risk değerlendirmesi yöntemi uygulaması hedeflenmiştir. Buna göre, işyerinin yapısına ve işyerinde yapılan işe göre risklerin belirlenmesi, periyodik olarak risklerin incelenmesi ve bu yönde tedbir alınması gerekmektedir. Maden işyerleri açısından da risk değerlendirmesinin yapılması oldukça önemlidir. Zira, madencilik faaliyetlerinin yapıldığı yerler işin niteliği gereği oldukça tehlikeli yerlerdir. Ancak, bu düşünce tarzı ile hazırlanan İSGK yürürlüğe girdikten sonraki süreçte ülkemizde ölümlü iş kazası rakamlarında arzu edilen düşüş yaşanmamıştır. Zira, 2012 yılında ölümle sonuçlanan iş kazalarının en çok yaşandığı ülkeler; Avusturya \%39, Kanada 
\%31,2, Hindistan \%31, Türkiye \%24,6 şeklinde sıralanmıştır. Türkiye dünyada ölümle sonuçlanan iş kazalarının en çok görüldüğü ülkeler içinde dördüncü olmuştur.

2012 yılında İSGK'nin yürürlüğe girmiş olmasına karşın, iş kazası yaşanan sektörler içinde, en çok iş kazası 8828 iş kazası ile kömür ve linyit maden ocaklarında meydana gelmiştir. 2013 y1lında da bu tablo değişmemiş maden ocaklarında görülen iş kazası sayısı artmıştır. 2013 yılında kömür ve linyit çıkartılan maden ocaklarında 11289 iş kazası yaşanmıştır. 2014 yılında kömür ve linyit çıkartılan maden ocaklarında 10026 iş kazası yaşanmıştır. Ancak, 2014 yılında kömür ve linyit çıkartılan maden ocaklarında yaşanan iş kazası sayısı 2013'e göre az olmakla birlikte, 2014 yılında madenlerde yaşanan iş kazalarında ölen işçi sayısı 2013'e göre daha fazla olmuştur. Zira, 2014 yılında Soma maden faciasının yaşanması üzerine 301 madenci hayatını kaybetmiş ve ilk beş aylık periyotta dahi madenlerde yaşanan iş kazası sonucu 700'ün üzerinde işçi yaşamını kaybetmiştir.

2015 yılında kömür ve linyit çıkartılan maden ocaklarında 7429 iş kazası yaşanmıştır. 2016 yılında ise bu sayı tekrar yükselişe geçmiş ve 8274 iş kazası yaşanmıştır. Ayrıca, 2016 yılında Türkiye genelinde iş kazalarında yaşanan ölüm sayısı da 2015 yılına göre artmıştır. 2015 yılında 1252 kişi iş kazası sonucu yaşamını yitirmişken, 2016 yılında 1405 kişi yaşamını yitirmiştir. Ayrıca, 2017 yılında iş kazası nedeniyle ölenlerin sayısı da 2016'ya göre artmıştır. 2017 yılında iş kazası nedeniyle ölen kişi sayısı 1633 olmuştur. 2018 yılında ise iş kazası sonucu 1923 işçi hayatını kaybetmiştir.

İŞGK’nin yürürlüğe girdiği 2012 yılından 2013 yılına madenlerde yaşanan iş kazalarının sayısı artmıştır. 2012'de İSGK'nin yürürlüğe girmesi ile madenlerde yaşanan iş kazası sayısının 2013 yılında azalması gerekirken, 2013 yılında artmıştır. Bunun nedeni, 2012 yılında İSGKnin getirmiş olduğu düzenlemeler uygulamaya yansımamıştır. Maden ocaklarında koruyucu ve önleyici tedbirler alınmamıştır. İSGK'nin öngördüğ̈̈ şekilde iş kazası yaşanmadan en baştan gerekli tedbirler alınmamıştır. Maden ocaklarında periyodik olarak risk değerlendirmesi de yapılmamıştır. Dolayısıyla İSGK'nin getirdiği kurallara riayet edilmemiştir.

2014 yılında çok sayıda madenci yaşamını yitirmiştir. Bunun nedeni 2014 yılında Soma maden faciası başta olmak üzere birçok madencinin hayatını 
kaybetmesi olmuştur. Ülkemizde bu dönemde maden ocaklarında çok sayıda işçinin hayatını kaybetmesinin altında yatan temel neden denetim zaafı ve uygulanan madencilik politikaları olmuştur. Zira, bu dönemde maden ocaklarında gerekli denetimler yapılmamıştır. Bir başka ifadeyle, denetim zaafları ortaya çıkmıştır. Denetim eksikliği ihmal zincirini de beraberinde getirmiştir. İşverenler ve işverenin görevlendirdiği nezaretçiler ile yetkili personel ve elemanlar gereken dikkat ve özeni göstermemiş, ihmalkar bir tutum sergilemiştir. Bu durumun ortaya çıkmasında uygulanan madencilik politikaları etkili olmuştur. Uygulanan madencilik politikalarında iş sağlı̆̆ ve güvenliğ değil, ekonomik kazanç ön planda tutulmuştur. Ayrıca, maden sahalarında görülen rödovans uygulamaları da maden kazalarında çok sayıda madencinin ölümüne neden olmuştur. Zira, rödovans uygulamaları ile çoğu zaman iş sağlığ ve güvenliği anlayışı birbiri ile örtüşmemektedir. Rödovanslı sahada işverenler de iş sağlığı ve güvenliğine gereken önemi vermemektedir. Ancak, işyerinde uygulanacak olan iş sağlı̆̆ ve güvenliği politikalarının, işverenin faaliyet gösterdiği işyeri veya işletmenin ekonomik, teknik ve mali özelliklerine göre farklılık göstermesi gerekmektedir.

2015 yılında maden ocaklarında yaşanan iş kazası sayısı 2014 yılına göre daha az olmuştur. Bunun temel nedeni, İSGK kuralları maden ocaklarında daha fazla uygulama alanı bulmuştur. Bu dönemde İSGK ile getirilen düzenlemeler tüm iş kollarında etkisini göstermiştir. Madencilik ve taş ocakları işkolunda da İSGK'nın getirmiş olduğu birçok yeni düzenleme uygulama alanı bulmuştur. Kanun ile madenlerde iş sağlığ 1 ve güvenliği önlemlerinin uygulanmasını sağlamak amacıyla yapılan denetimler arttırılmıştır. Ancak, 2015'den 2016'ya madenlerde yaşanan iş kazası sayısı artmıştır. Bu durum 2017 ve 2018 yı1larında da devam etmiştir. Bunun temel nedeni denetim eksikliği olmakla birlikte, bir diğer neden de, maden ocaklarında iş sağlığı ve güvenliğine dönük gerekli tedbirlerin alınmamasıdır.

$\mathrm{Bu}$ doğrultuda tarihi süreç içinde maden işçilerine yönelik iş sağlığ 1 ve güvenliği alanında birçok gelişme yaşanmıştır. Bu durum kanuni düzenlemelere de sirayet etmiştir. Ancak, uygulamada çoğu zaman eksiklikler görülmektedir. Maden işçilerine yönelik iş sağlığı ve güvenliği alanında yapılan kanuni düzenlemelerin anlam kazanabilmesi ve işçilerin daha sağlıklı ve güvenli bir ortamda çalışabilmesi için uygulamada yasal düzenlemelere riayet edilmesi, yasal sınırlamalara uyulması ve madenlerin düzenli şekilde denetlenmesi 
gerekmektedir. Aksi halde madenlerde yaşanan ölümlerin önüne geçmek mümkün olmayacaktır.

Hakem Değerlendirmesi: Dış bağımsız.

Çıkar Çatışması: Yazar çıkar çatışması bildirmemiştir.

Finansal Destek: Yazar bu çalışma için finansal destek almadığını beyan etmiştir.

Peer-review: Externally peer-reviewed.

Conflict of Interest: The author has no conflict of interest to declare.

Grant Support: The author declared that this study has received no financial support. 


\section{Kaynakça/References}

Akı, E. (2014). 6331 sayılı iş sağlığı ve güvenliği kanunu ve çalışma yaşamına etkileri. Dokuz Eylül Üniversitesi Hukuk Fakültesi Dergisi, 15, 3-24.

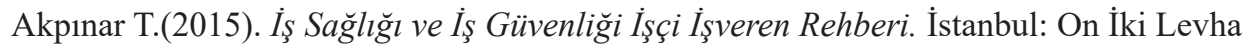
Yayıncilik.

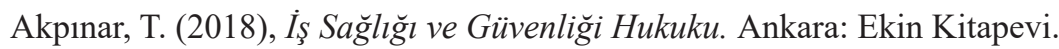

Akpınar, T. ve Çakmakkaya, B. Y. (2014), İş Sağlığı ve Güvenliği Açısından İşverenin Risk Değerlendirme Yükümlülüğü. Çalışma ve Toplum, 40, 273-304.

Aktuna, A. (2017). Tarım sektöründe çalışanların iş sağlı̆̆ı ve güvenliği çerçevesinde bilgi, tutum ve alg1 düzeyleri: Tekirdağ Süleymanpaşa örneği. Namık Kemal Üniversitesi, Çalışma İktisadı Anabilim Dalı, Yüksek Lisans Tezi, Tekirdağ.

Akyiğit, E. (2016). Iş̧ Hukuku. Ankara: Seçkin Yayıncılık.

Arslan-Ertürk, A. (2014), 6552 Sayılı kanunun 5510 sayılı sosyal sigortalar ve genel sağlık sigortaları kanununa getirdiği bazı önemli değişikliklerin değerlendirilmesi. Marmara Üniversitesi Hukuk Fakültesi Hukuk Araştırmaları Dergisi, 20, 247-272.

Balkır, Z. G. (2012). İş sağlı̆̆1 ve güvenliği hakkının korunması: işverenin iş sağlığı ve güvenliği organizasyonu. Sosyal Güvenlik Dergisi, 2, 56-91.

Blank, D. J., Aziz N. I. (2009). Developments In Coal Mine Methane Drainage and Utılisation In Australia, In Proceedings Of The Ninth International Mine Ventilation Congrees, Mining Engineering, India: Ingian School Of Mines Ubiversity Dhanbad.

Bozoğlan, M. (2010). Ülkemizde Kömür Madenciliğinde $\dot{I}_{S ̧}$ Sağliğl ve Güvenliği Mevzuatının Gelişimi 1867-2010, Ankara: Korza Yayıncılık.

Baycık, G. (2006), Iş̧ Hukuku ve Sosyal Güvenlik Hukuku Açısından Maden İşçileri. Ankara: Yetkin Yayınları.

Çalışma ve Sosyal Güvenlik Bakanlığı Eğitim ve Araştırma Merkezi, (2017). Türkiye'de İş Sağlığı ve Güvenliği Algısı Araştırma Raporu, Ankara: ÇSGB.

Çelik, N., Caniklioğlu N. ve Canbolat T. (2017). Işs Hukuku Dersleri, İstanbul: Beta Yayıncılik.

Çetindağ, Ş. (2010). İş Sağlığı ve Güvenliğinin Tarihsel Gelişimi Mevzuattaki Güncel Durum", http://dosya.toprakisveren.org.tr/makale/ 2010-86-serifcetindag.pdf (08.01.2020).

Çiçek, Ö. ve Öçal, M. (2016). Dünyada ve Türkiye'de iş sağlı̆̆ı ve iş güvenliğinin tarihsel gelişimi. HAK-İ̧̧ Uluslararası Emek ve Toplum Dergisi, 5, 106-129.

Demir, F. (2006/2007), Atatürk Dönemi Çalışma Hayatımız. TÜHIS İş Hukuku ve İktisat Dergisi, 20,1-20.

Demircioğlu M. ve Tankut C. (2016), İş Hukuku, İstanbul: Beta Yayıncılık.

Düzgün, H. Ş. (2014). 28 Ekim 2014 tarihinde Ermenek’te Bir Yer Altı Kömür Ocağında Meydana Gelen Facia İle İlgili Değerlendirmeler. 1-10,https://bilimakademisi.org/wpcontent/uploads/2014/11/ ermenek _ 10.11.2014.pdf(17.02.2020). 
Eddington, I. (2006) An historical explanation of the development of occupational health and safety and the important position it now occupies in society. In: AEC 2006: Queensland Safety Forum, 21-23 Jun 2006, Brisbane, Australia.

Filizöz, B. ve Kocabacak A. (2016), Türkiye’de İş Sağlı̆̆l ve Güvenliği Uygulamalarl, Ankara: Seçkin Yayıncılık.

Günay, Ö. (2017). Maden Hukuku Tanımlar-İlkeler-Kavramlar. Ankara: Seçkin Yayıncılık. Güneş, T. (2018). Kişisel Görüşme, DİSK-İstanbul.

Gürbüz, T. (2014). 6356 Sayılı Sendikalar ve Toplu İş Sözleşmesi Kanunu'nun Avrupa Birliği ve Uluslararası Çalışma Örgütü Normları Bakımından Değerlendirilmesi, Çalışma ve Sosyal Güvenlik Bakanlığı Avrupa Birliği Koordinasyon Başkanlığı. Avrupa Birliği Uzmanlık Tezi, Ankara.

Güven, T. (2015). Zonguldak Kozlu’da Kömür Madenciliği: İşletmecilik ve Çalışma Hayatı (1848-1921), Zonguldak: Bülent Ecevit Üniversitesi Yayınları No: 5.

Güzel, A., Okur, A. R. ve Caniklioğlu N.(2016). Sosyal Güvenlik Hukuku. İstanbul: Beta Yayıncilik.

https://calismaortami.fisek.org.tr/icerik/maden-kazalari/ (09.08.2020).

https://www.britannica.com/event/Monongah-mining-disaster-of-1907 (01.08.2020).

http://iskanunu.com/genel/633-is-sagligi-ve-guvenligi-icin-cagdas-duzenlemeler-geldi/ (05.08.2020).

https://www.ailevecalisma.gov.tr/(12.01.2020).

https://www.ilo.org/dyn/normlex/en/f?p=NORMLEXPUB:12100:0::NO::P12100_ILO_ CODE:C155.(15.01.2020).

https://www.ilo.org/dyn/normlex/en/f?p=NORMLEXPUB:12100:0::NO::P12100_ILO_ CODE:C161.(19.01.2020).

http://www.mining-technology.com/features/feature-world-worst-coal-mining-disasterschina .(27.07.2020).

https://whc.unesco.org/uploads/nominations/1214.pdf .(30.07.2020).

Jonathan, G., K., \& Mbogo, R. W. (2016), Maintaining health and safety at workplace: employee and employer's role in ensuring a safe working environment. Journal of Education and Practice www.iiste.org ISSN 2222-1735 (Paper) ISSN 2222-288X (Online). 7, 1-7.

Karadeniz, O. (2012). Dünyada ve Türkiye'de iş kazaları ve meslek hastalıkları ve sosyal koruma yetersizliği. Çalışma ve Toplum, 34, 15-73.

Karakoç, K. (2014). Osmanlı'dan Günümüze Maden Mevzuatı ve Bor Madenciliği Özelleştirme ve Bor Politikaları Üzerine Düşünceler”, Eskişehir: II. Uluslararası Bor Semponumu, 23-25 Evlül 2004.

Kaştan, Y. (2016). Osmanlı İmparatorluğunda kömür ocaklarının işletilmesi (1832-1918). Osmanlı Medeniyeti Araştırmaları Dergisi, 2, 1-26. 
Keskin, Ö. (2011). Osmanlı Devleti'nde maden hukukunun tekâmülü (1861-1906). OTAM, 29, 125-148.

Kılkış, İ. (2012). İşverenin iş sağlı̆̆1 ve güvenliği eğitimi verme yükümlülüğü üzerine bir inceleme. Çalışma İlişkileri Dergisi, 3, 23-47.

Koç, Y. (2010). Türkiye İşçi Sınıfı Tarihi Osmanlı'dan 2010'a. Ankara: Epos Yayınları.

Koç, Y. (2016). Türkiye İş̧̧i Sınıfi Tarihi Osmanlı'dan 2016'ya, Ankara: Epos Yayınları.

Kol, İ. (2016). İskele iş Sağlığı ve Güvenliğinde Operasyonel Dsiplin, Gedik Üniversitesi, İş Sağlığı ve Güvenliği Anabilim Dalı, Yüksek Lisans Tezi, İstanbul.

Korkmaz, F. ve Alp, N. S. (2016). Bireysel İş Hukuku, Ankara: Seçkin Yayıncılık.

Kurt, R. (2013). Herkes İçin İ̧s Să̆lı̆̆ ve Güvenliği Rehberi. Ankara: Seçkin Yayıncıllk.

Makal A. (2005). Zonguldak ve Türkiye Toplumsal Tarihinin Acı Bir Deneyimi Olarak “İş Mükellefiyeti. 05 Bienali Bildiriler Kitabı, Zonguldak.

Merwe, J. N., \& Coalbrook, B. (2006). What Did We Really Learn. The Journal of The Southern African Institute of Mining and Metallurgy.

Mollamahmutoğlu H., Astarlı M., Baysal U, (2014), Işs Hukuku, Ankara: Turhan Kitapevi.

Öztoprak, S. (2015). Maden Ocaklarının Özel Hukuk Kişileri Tarafindan İşletilmesi, Ankara: Yetkin Yayınevi.

Öztürk G. S. (2015). İ̧s Să̆ğğg ve Güvenliği Yükümlülüklerinin Yerine Getirilmemesinin Hukuki, Idari ve Cezai Sonuçları. İstanbul: Beta Yayıncılık.

Özveri, M. (2015). İşçi Sağlığı İş Güvenliği ve İş Cinayetleri. İstanbul: Birleşik Metal İş Yayınlar1.

Reece, D. (2018). "Risk Değerlendirme ve Acil Durum Hazırlığı", III. Uluslararası Madenlerde İş Sağlığı ve Güvenliği Konferansı ve Sergisi, Türkiye Madenciler Derneği (TMD), İstanbul.

Selek, H. S. (2018). İş Să̆lı̆̆ı ve Güvenliği (ISG) Temel Konular. Ankara: Seçkin Yayıncilık.

Sarıtaş, D. Ö. (2010), Cumhuriyet Dönemi Roma Vergi Sistemi, Anadolu Üniversitesi Sosyal Bilimler Enstitüsü Özel Hukuk Anabilim Dalı, Doktora Tezi, Eskişehir.

Sökmen, M. E. (2016), Yer altı Madenlerinde Personel Takip ve Haberleşme Sistemlerinin İncelenmesi, Çalışma ve Sosyal Güvenlik Bakanlığı İş Sağlığı ve Güvenliği Genel Müdürlüğü, İş Sağlığı ve Güvenliği Uzmanlık Tezi, Ankara, 2016.

Sökmen, M. E. (2019), Madencilik Sektöründe Iş̧ Güvenliği Uzmanlı̆̆l Eğitimlerinin Karşılaştırmalı Olarak Incelenmesi ve Değerlendirilmesi, Hacettepe Üniversitesi Maden Mühendisliği Anabilim Dalı Yüksek Lisans Tezi, Ankara.

Sümer, H. H. (2017). Işs Sağlı̆̆l ve Güvenliği Hukuk. Ankara: Seçkin Yayıncılık.

Süzek, S. (2017). İ̧̧ Hukuku. İstanbul: Beta Yayıncılık.

Şen, M. (2015). İş sağlığı ve güvenliği kavramı, tarihsel gelişimi ve dayanakları. MÜHFD, 4, 117-142. 
Şenocak, H. (2009). Sosyal güvenlik sistemini oluşturan bileşenlerin tarihi süreç ışığında değerlendirilmesi. Sosyal Siyaset Konferansları Dergisi, 56, 399-468.

Temizok, N. (2018). “Dünya' da ve Türkiye’de Kömür” TMMOB Oda Raporu, Türkiye’nin Enerji Görünümü 2018, Ankara: TMMOB Türkiye Makine Mühendisleri Odas1.

Tiftik, M. ve Adıgüzel, A. (2016). İş sağlığı ve güvenliği kanunu'na göre genel hizmet sözleşmelerinde işverenin işçiyi koruma borcu. Yıldırım Beyazıt Hukuk Dergisi, 1(1), 319-366.

Tiryaki, N. (19.04.2018), Kişisel Görüşme, Genel Maden İşçileri Sendikas1-Zonguldak Merkez.

Topaloğlu, M. (2011). Maden Hukuku. Ankara: Karhan Kitapevi.

Topaloğlu, M.(2014). “Maden Kazaları Karşısından Maden Ruhsat Sahibinin ve Rödovansçının Hukuki Durumu”, Sektörden Haberler Bülteni, Türkiye Madenciler Derneği, S.52.

Tozkoparan, G. ve Taşoğlu, J. (2011). İş sağlığı ve güvenliği uygulamaları ile ilgili işgörenlerin tutumlarını belirlemeye yönelik bir araştırma. Uludağ Üniversitesi İktisadi ve Ídari Bilimler Fakültesi Dergisi, XXX, 181-209.

Turhan, M. (2016). “Türkiye'de Maden Hukukunun Tarihi Gelişimi ve Bazı Ülkelerle Mukayesesi”, Maden Hukuku Bildirimler Kitabı, der. Ali Şafak Ballı. Ankara: Astana Yayınları.

Turgay, F. (2017). “1960-1963 Dönemi İşçi Eylemlerine Aşağıdan Bakmak”, İnsan Insan, 13, 253-263.

Tuyan, M. (1981). "Madenciliğimizin Tarihsel Gelişimi”, Türkiye Madencilik Bilimsel ve Teknik 7 . Kongresi, Ankara.

Türkiye Barolar Birliği İnsan Hakları Merkezi. (2014). Soma Maden Faciası Raporu, Ankara: Türkiye Barolar Birliği.

Türkiye Maden İşçileri Sendikası, Madencilik Sektöründeki Sorunların Araştırılarak Alınması Gereken Önlemlerin Belirlenmesi Amacıyla Kurulan Meclis Araştırma Komisyonuna Sunulan Türkiye Maden Işşileri Sendikası 'nın Görüşleri, Mart 2010.

Türkiye Maden Mühendisleri Odası. (2011). Madencilik Sektörü ve Politikaları Raporu, Ankara: TMMOB.

Uluslararası Çalışma Örgütü. (2016). Türkiye Kömür Madenciliği Sektöründe Sözleşmesel Düzenlemeler: Gerçekleşme Biçimleri, Boyutları, Nedenleri, Yasal Nedenleri ve İSG Üzerindeki Etkisi, Ankara; ILO Türkiye Ofisi.

Ünlütürk-Ulutaş, Ç. ve Ulutaş, T. B. (2015). Angarya ve zorla çalıştırma: uluslararası düzenlemeler ve yüksek mahkeme kararları 1şı̆̆ında bir değerlendirme. Uluslararası Sosyal Araştırmalar Dergisi, 8, 327-339.

Yamakoğlu, E. (2016). İşverenin İşyeri Hekimi İ̧̧ Güvenliği Uzmanı Çalıştırma Yükümlülüğ̈̈. Ankara: Seçkin Yayıncılık.

Yılmaz, F. (2009) Avrupa Birliği ve Türkiye’de İş Sağlığı ve Güvenliği: Türkiye’de İş Sağlığı ve Güvenliği Kurallarının Etkinlik Düzeyinin Ölçülmesi, İstanbul Üniversitesi Sosyal Bilimler Enstitüsü, Yüksek Lisans Tezi, İstanbul. 
